\title{
Recent Studies on the Antimicrobial Activity of Transition Metal Complexes of Groups 6-12
}

\author{
Sara Nasiri Sovari and Fabio Zobi * \\ Department of Chemistry, Fribourg University, Chemin du Musée 9, 1700 Fribourg, Switzerland; \\ sara.nasirisovari@unifr.ch \\ * Correspondence: fabio.zobi@unifr.ch
}

Received: 6 April 2020; Accepted: 6 May 2020; Published: 9 May 2020

check for updates

\begin{abstract}
Antimicrobial resistance is an increasingly serious threat to global public health that requires innovative solutions to counteract new resistance mechanisms emerging and spreading globally in infectious pathogens. Classic organic antibiotics are rapidly exhausting the structural variations available for an effective antimicrobial drug and new compounds emerging from the industrial pharmaceutical pipeline will likely have a short-term and limited impact before the pathogens can adapt. Inorganic and organometallic complexes offer the opportunity to discover and develop new active antimicrobial agents by exploiting their wide range of three-dimensional geometries and virtually infinite design possibilities that can affect their substitution kinetics, charge, lipophilicity, biological targets and modes of action. This review describes recent studies on the antimicrobial activity of transition metal complexes of groups 6-12. It focuses on the effectiveness of the metal complexes in relation to the rich structural chemical variations of the same. The aim is to provide a short vade mecum for the readers interested in the subject that can complement other reviews.
\end{abstract}

Keywords: antimicrobial; transition metals; complex; organometallic; drug-resistant

\section{Introduction}

Antimicrobial resistance has become a global concern ultimately affecting humans' ability to prevent and treat an increasing number of infections caused by bacteria, parasites, viruses and fungi and the success of surgery and cancer chemotherapy. It occurs naturally over time, usually through genetic changes of the pathogens when exposed to antimicrobial drugs. One of the causes for the emergence of the problem is the overuse and misuse of existing antibiotics, which fueled the evolution of pathogens resistant to the current library of antimicrobial agents [1,2]. As a result, available medicines become ineffective, infections persist in the body, increasing the risk to patients' health, spreading and health care costs. Multidrug resistant bacteria, such as Enterococcus faecium, Staphylococcus aureus, Klebsiella pneumoniae, Acetinobacter baumanii, Pseudomonas aeruginosa, and Enterobacteriaceae ("ESKAPE") species, are a major concern of the World Health Organization (WHO) and health authorities. These pathogens cause a large number of victims worldwide [3-5]. As an example, methicillin-resistant Staphylococcus aureus (MRSA) is one of the most critical causes of healthcare-related or community-related infections, because of the multiple resistances to antibiotics and the toxins produced [6]. It is, therefore, evident that there is an urgent need for the development of new antimicrobial agents with more effective mechanisms of action [7].

While the problem is escalating, major pharmaceutical companies have interrupted their antibiotic drug discovery programs, leaving academia at the forefront of the discovery of new classes of active compounds, especially for Gram-negative bacteria [8,9]. The classical approach of medicinal chemists based exclusively on organic molecules is poised to have a short-term limited impact because pathogens will adapt and develop resistance to new drugs. Furthermore, as recently pointed out by Frei [10], 
only $\sim 25 \%$ of the compounds currently in clinical development represent entirely new structural classes, with the remaining $75 \%$ of drugs being merely derivatives and modifications of already approved antibiotics. Thus, there is not just an urgent need for new antibiotics, but also a need for entirely new classes of molecules for the purpose. Transition metal complexes offer this possibility. They possess a wide range of three-dimensional geometries, virtually infinite possibilities to design their coordination sphere in order to affect their substitution kinetics, charge, lipophilicity biological targets and modes of action. Such complexes, however, are still (prejudicially) ignored by pharmaceutical companies despite the fact that several of them are used in hospitals worldwide. For example, arsphenamine, also known as Salvarsan or compound 606, is an effective drug for the treatment for syphilis; cisplatin is a chemotherapeutic agent, administered intravenously, and used to treat a number of cancers (e.g., testicular, ovarian, cervical, breast, bladder, head and neck, esophageal cancer); auranofin is a gold salt approved by the $\mathrm{WHO}$ as an antirheumatic agent; technetium sestamibi (trade name Cardiolite) is a pharmaceutical agent used in nuclear medicine imaging to visualize the myocardium.

In the last ten years, inorganic and organometallic transition metal medicinal chemists have begun to develop new antimicrobial agents with great promise and remarkable success. Complexes of virtually all ions of the transition periods have been tested. In this article, we present an overview of antimicrobial transition metal (groups 6-12) complexes published in the scientific literature in the last five years. We only describe inorganic and organometallic complexes of group 6-12 with a few exceptions. Thus, e.g., silver and iron complexes are not included. Antimicrobial iron and silver complexes and (nano)materials have been recently reviewed elsewhere [11-25]. Due to the growing interest in the field, recent reviews and prospective on the antibacterial applications of transition metal complexes have appeared [10,26-29]. This work aims at being complementary to those, including some important common seminal examples but mostly species not included by the other authors.

\section{Group 6}

\subsection{Chromium Complexes}

Schiff base complexes of chromium are most commonly studied for their antimicrobial efficacy, but the species have seldom shown high potency. Kumar et al. synthesized a new class of tetradentate Schiff bases as ligands and their corresponding chromium(III) complexes (1, Figure 1) by using $\mathrm{CrCl}_{3}$ as the metal ion source [30]. The antimicrobial activities of the chromium(III) complexes were tested against S. aureus (Gram-positive), E. coli and P. aeruginosa (Gram-negative) bacterial strains, but their efficacies were lower than the standard drug, i.e., ampicillin. Rathi et al. reported the preparation of thiophene based macrocyclic Schiff base complexes from the reaction of succinohydrazide and thiophene-2,5-dicarbaldehyde in the presence of chromium(III) and iron(III) salts of chloride, nitrate and acetate (2, Figure 1) [31]. The antimicrobial activities of all synthesized complexes were tested against bacterial strains, such as B. subtilis and E. coli, and fungal strains, such as S. cerevisiae and C. albicans. The data showed good activity of compounds against all tested microbial strains with the MIC values in the range of $8-128 \mu \mathrm{g} / \mathrm{mL}$. In 2017, Shaabani et al. prepared bridged chromium(III) complexes, of hydrazine Schiff bases tridentate ligands and azide (3, Figure 1) [32]. The complexes, however, were not particularly effective against tested pathogens with MIC values $(\sim 1250 \mu \mathrm{g} / \mathrm{mL})$ higher than standard drugs (MIC $=8-28 \mu \mathrm{g} / \mathrm{mL}$ ). Kafi-Ahmadi and coworkers synthesized thiourea derivatives as Schiff base ligands (4, Figure 1) and their chromium(III) complexes [33]. The complexes were tested for their antibacterial activities against clinically important bacteria, such as E. coli, S. aureus, and B. subtilis, and they showed good activities against all strains, comparable to that of streptomycin as the standard. The mechanism of action of these complexes is unknown. The authors suggested that chelation theory might help explain the biological activities of the metal chelates. This phenomenon relates to a decrease in the polarity of the metal ion due to overlap metal and ligand orbitals, resulting in partial sharing of the positive charge of the metal ion with donor groups and possibly electron delocalization over the whole molecule [33-36]. 

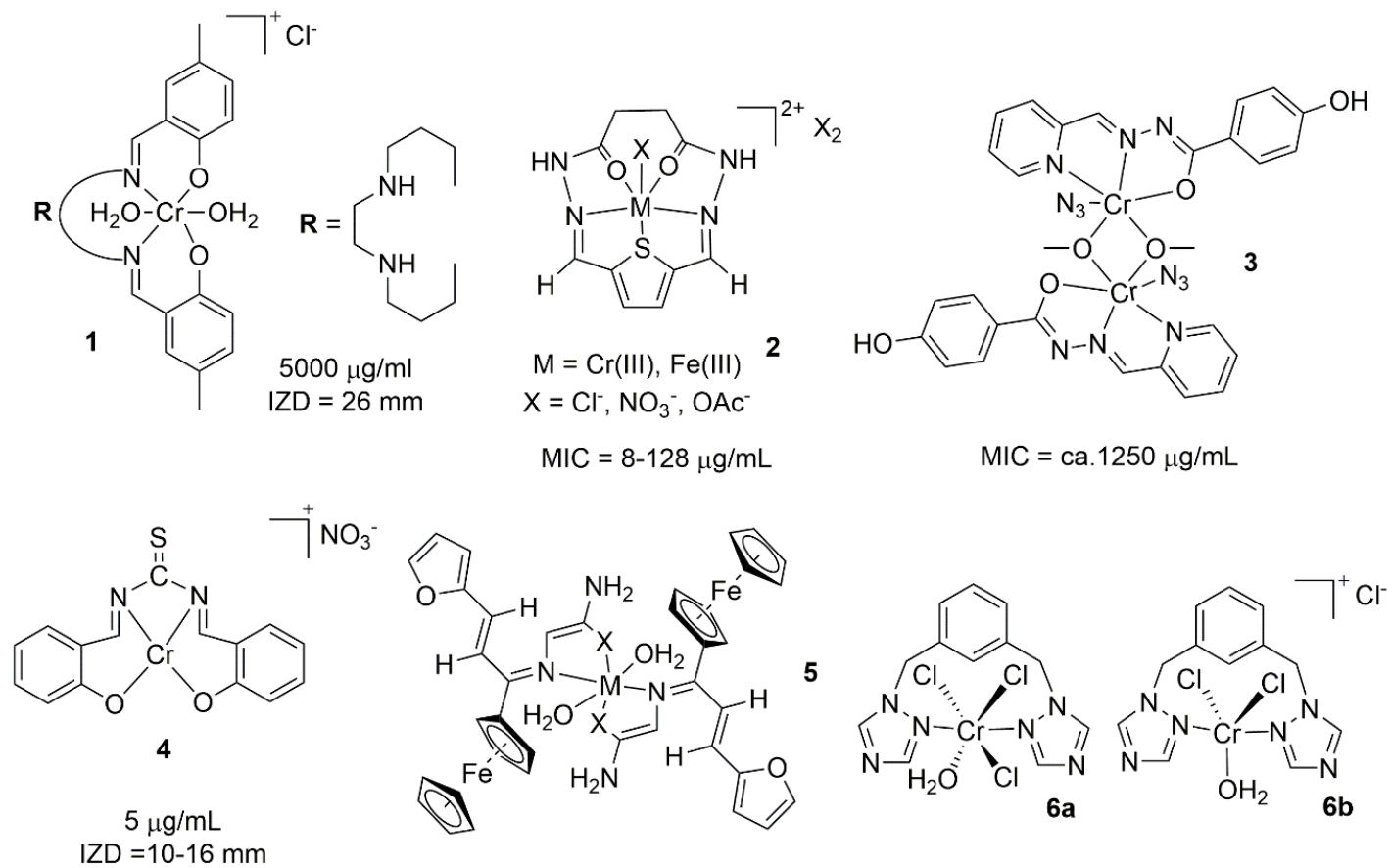
$\mathrm{M}=\mathrm{Pb}(\mathrm{II}), \mathrm{Bi}(\mathrm{III}), \mathrm{Cu}(\mathrm{II}), \mathrm{Cr}(\mathrm{III}), \mathrm{Ba}(\mathrm{III})$, $\mathrm{Cd}(\mathrm{II}), \mathrm{Fe}(\mathrm{II}), \mathrm{Ni}(\mathrm{II}), \mathrm{Sn}(\mathrm{II}), \mathrm{Nd}(\mathrm{II})$

$\mathrm{MIC}=7.8-15.6 \mu \mathrm{g} / \mathrm{mL}$

$$
\begin{gathered}
X=0, S \\
3000 \mu \mathrm{g} / \mathrm{ml} \\
I Z D=11-24 \mathrm{~mm}
\end{gathered}
$$<smiles>COc1cccc(/C=N/c2ccccc2O)c1O</smiles>

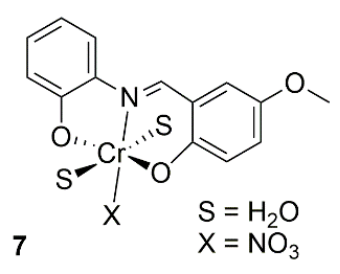

$\mathrm{MIC}=4.2-7.5 \mu \mathrm{g} / \mathrm{mL}$

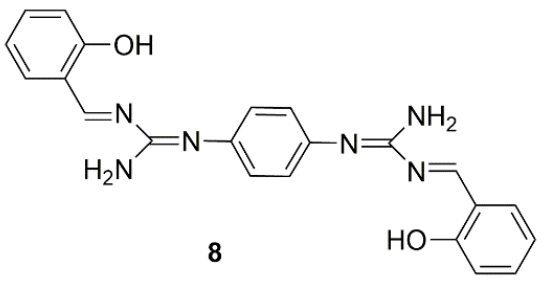

for $\mathrm{Cr}$ complex (structure unknown) $2 \mathrm{mg} / \mathrm{mL}, I Z D=9 \mathrm{~mm}$

Figure 1. Structural formula of selected antimicrobial chromium(III) complexes and corresponding ligands. $\mathrm{MIC}=$ minimal inhibitory concentration; $\mathrm{IZD}=$ inhibition zone diameter at given concentration.

In 2018, Liu et al. introduced a Schiff base ligand, 1-ferrocenyl-3-(2-furyl) propenone diamino (thio) urea, and coordinated it to a range of metal ions (e.g., $\mathrm{Pb}(\mathrm{II}), \mathrm{Bi}(\mathrm{III}), \mathrm{Cu}(\mathrm{II}), \mathrm{Cr}(\mathrm{III}), \mathrm{Ba}(\mathrm{III}), \mathrm{Cd}(\mathrm{II})$, $\mathrm{Fe}(\mathrm{II}), \mathrm{Ni}(\mathrm{II}), \mathrm{Sn}(\mathrm{II})$ and $\mathrm{Nd}(\mathrm{II}), 5$, Figure 1) [37]. All compounds were screened for their antimicrobial activities against bacteria, such as E. coli, S. aureus and MRSA, also fungi, such as C. albicans and A. flavus. The complexes were not particularly effective. The zones of inhibition ( $\mathrm{mm}$ ) were found in a range between 11 and $24 \mathrm{~mm}(3 \mathrm{mg} / \mathrm{mL}$ concentrations) with the chromium(III) complex being amongst the least effective compounds. In 2018, tridentate triazole based ligands of chromium(III) complexes were reported by Murcia et al. (6a and $\mathbf{6} \mathbf{b}$, Figure 1) [38]. The antimicrobial activities of both ligands and complexes were tested against a wide range of bacterial and fungal strains of clinical relevance. The results indicated that the chromium(III) complexes were more potent than free ligands and more effective against fungi than bacteria. The complexes $\mathbf{6 a}$ and $\mathbf{6 b}$ showed MIC values in the range of 7.8 to $15.6 \mu \mathrm{g} / \mathrm{mL}$. A study on azomethine chelates of $\mathrm{Cu}(\mathrm{II}), \mathrm{Pd}(\mathrm{II}), \mathrm{Zn}$ (II) and $\mathrm{Cr}(\mathrm{III})$ with tridentate dianionic azomethine OVAP ligand (where OVAP $=2$-[(2-hydroxyphenylimino)methyl]-6-methoxyphenol), was carried out by Abu-Dief et al. (7, Figure 1) [39]. All OVAP metal complexes were screened against a broad-spectrum of antimicrobial strains (bacterial strains: M. luteus, E. coli and S. marcescence; fungal strains: A. flavus, G. candidum and F. oxysporum) and showed MIC values between 4.25 and $7.50 \mu \mathrm{g} / \mathrm{mL}$. 
The investigated azomethine metal chelates revealed significantly enhanced antimicrobial activities in comparison to the free ligand (MIC $=9.0-10.75 \mu \mathrm{g} / \mathrm{mL}$ ) and showed comparable activities to ofloxacin and fluconazol. Very recently, copper(II), nickel(II), cobalt(II), manganese(II), iron(III), chromium(III), bismuth(III), and zinc(II) complexes of the guanidine Schiff bases 8 (Figure 1) were reported [40]. Compounds were screened against $S$. aureus (Gram-positive), P. aeruginosa (Gram-negative) and the fungi strains, such as $C$. albicans and $A$. niger. In general, metal complexes were found to be more toxic than ligand $\mathbf{8}$ and showed greater activity than neomycin and the naturally occurring fungicide cycloheximide. Several other chromium metal complexes have been recently tested for their antimicrobial efficacy but were not found to be active [41-45].

\subsection{Molybdenum Complexes}

In comparison to chromium complexes, only a few studies on the antimicrobial potential of molybdenum metal complexes have appeared over the last decade in the literature, while we are not aware of tungsten species having been reported lately. A series of cis-dichloro/dibromodioxidobis (2-amino-6-substitutedbenzothiazole) molybdenum(VI) complexes (9, Figure 2) were reported by Saraswat et al. in 2013 [46]. The complexes of dihalodioxidomolybdenum(VI) have played a special role in the higher valent molybdenum enzymes such as sulfite oxidase, nitrate reductase, xanthine oxidase and xanthine dehydrogenase during biological processes [47,48]. The authors reported the antibacterial activities of the species against $P$. aeruginosa, $S$ aureus and K. pneumoniae and antifungal activities against $A$. flavus and A. niger. The results showed that derivatives of 9 were generally as active as ampicillin against bacteria strains, and most effective against $P$. aeruginosa and K. pneumonia, while their antifungal MIC values were in the range of $10-20 \mu \mathrm{g} / \mathrm{mL}$.<smiles>[R]c1ccc2nc(N)sc2c1OCCON(C)C(=O)c1c([R])ccc2nc(N)sc12</smiles>

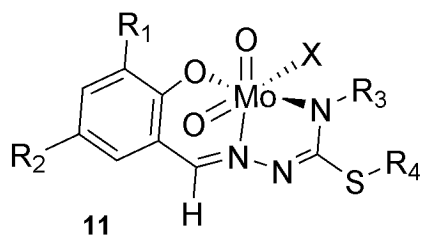

$\mathrm{L}_{1}=\mathrm{R}_{1}, \mathrm{R}_{2}, \mathrm{R}_{3}, \mathrm{R} \mathrm{R}_{4}: \mathrm{Cl}, \mathrm{Cl}, \mathrm{C}_{2} \mathrm{H}_{5}, \mathrm{C}_{4} \mathrm{H}_{9}$ $L_{2}=R_{1}, R_{2}, R_{3}, R_{4}: O_{2} H_{5}, H, C_{2} H_{5}, C_{3}$

$$
\mathrm{X}=\mathrm{CH}_{3} \mathrm{OH}, \text { py }
$$$$
\text { MIC }=62.5-500 \mu \mathrm{g} / \mathrm{mL}
$$<smiles>[X]c1ccc(O)c(/C=N/N=C(S)SCc2ccccc2)c1</smiles>

$X=\mathrm{H}, \mathrm{NO}_{2}, \mathrm{Br}$

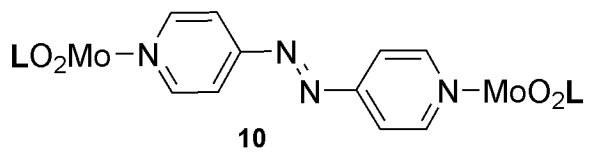

$\mathrm{MIC}=4.2-7.5 \mu \mathrm{g} / \mathrm{mL}$

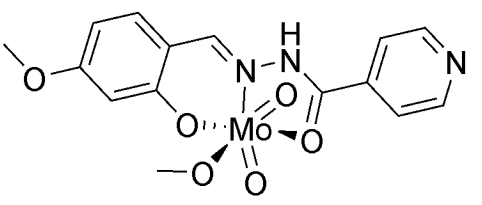

12

$\mathrm{MIC}=265.9 \mu \mathrm{g} / \mathrm{mL}$

Figure 2. Structural formula of selected antimicrobial molybdenum(VI) complexes and corresponding ligands.

In 2015, Biswal et al. reported isostructural 4,4'-azopyridine (4,4'-azpy) pillared binuclear dioxomolybdenum(VI) complexes of formula $\left[\left(\mathrm{MoO}_{2} \mathrm{~L}_{1}\right)_{2}\left(4,4^{\prime}\right.\right.$-azpy $\left.)\right],\left[\left(\mathrm{MoO}_{2} \mathrm{~L}_{2}\right)_{2}\left(4,4^{\prime}\right.\right.$-azpy)] and 
$\left[\left(\mathrm{MoO}_{2} \mathrm{~L}_{3}\right)_{2}\left(4,4^{\prime}\right.\right.$-azpy) $]$ (where $\mathrm{L}_{\#}=$ Schiff base ligand, 10, Figure 2) [49]. The ligands and molybdenum(VI) complexes were tested against B. cerus and L. monocytogenes (Gram-positive), E. coli and S. aureus (Gram-negative) bacteria by the disc diffusion method. The compounds exhibited different degrees of antimicrobial activities at a concentration of $10 \mu \mathrm{g}$ per disc against the pathogens with antimicrobial activities comparable with those of common antibiotics ampicillin and tetracycline (as standard drugs). Schiff base ligands also showed moderate to good antimicrobial activities against all test microorganisms and were more active than their corresponding complexes. In 2019, Çelen et al. synthesized a group of thiosemicarbazonato-based ligands (2-hydroxy-3-methoxy/3,5-dibromo benzaldehyde 4-phenyl/ethyl-S-methyl/butyl thiosemicarbazones), and then coordinated the ligands through the ONN set to the molybdenum(VI) ion center to prepare cis-dioxomolybdenum(VI) complexes (11, Figure 2) [50]. All ligands and the complexes were tested $(10 \mathrm{mg} / \mathrm{mL})$ against C. albicans, E. coli, P. aeruginosa and S. aureus. The results confirmed the antimicrobial activities of all thiosemicarbazones and their dioxomolybdenum(VI) complexes and MIC values were in the range of $62.5-500 \mu \mathrm{g} / \mathrm{mL}$. In 2020, Sang et al. reported the synthesis and the antimicrobial properties of a dioxidomolybdenum(VI) complex of $N^{\prime}$-(2-hydroxy-4-methoxybenzylidene)isonicotinohydrazide (12, Figure 2) [51]. The free ligand showed modest antibacterial activity against $S$. aureus and E. coli (MIC $=\sim 5 \mathrm{mmol} / \mathrm{L}$ ), however, the molybdenum complex showed higher antibacterial activity against $E$. coli with MIC value of $0.62 \pm 0.04 \mathrm{mmol} / \mathrm{L}$. Finally, a report on two cationic cluster complexes based on the $\left\{\mathrm{Mo}_{6} \mathrm{I}_{8}\right\}^{4+}$ core with (4-carboxybutyl)triphenylphosphonium and 4-carboxy-1-methylpyridinium as apical ligands, indicated no antimicrobial activities of the species [52].

\section{Group 7}

\subsection{Manganese Complexes}

Several manganese complexes have been reported in the field, including photoactivatable CO-releasing molecules, which are described separately in the following section. In 2013, Zampakou et al. prepared $\left[\mathrm{KMn}(\mathrm{oxo})_{3}(\mathrm{MeOH})_{3}\right]$ and $\left[\mathrm{Mn}(\mathrm{erx})_{2}\right.$ (phen)] complexes by reacting $\mathrm{MnCl}_{2}$ with the quinolone antibacterial drug oxolinic acid (Hoxo), enrofloxacin (Herx) and the $N, N^{\prime}$-donor heterocyclic ligand 1,10-phenanthroline (phen), respectively (13, Figure 3) [53]. Complexes were found significantly active against three Gram-positive (B. subtilis, B. cereus and S. aureus) and two Gram-negative (X. campestris and E. coli) bacterial strains with half-minimum inhibitory concentration (MIC) between 1.2 and $44 \mu \mathrm{g} / \mathrm{mL}$. In 2018, Barmpa et al. reported similar types of manganese(II) complexes by using the quinolone antimicrobial agent sparfloxacin (Hsf) and flumequine (Hflmq) with or without nitrogen-donor heterocyclic ligands 1,10-phenanthroline (phen), 2,2'-bipyridine (bipy), 2,2'-bipyridylamine (bipyam) or pyridine (py) (14, Figure 3) [54]. The in vitro antimicrobial tests gave MIC values for the complexes in the range of, or slightly better than free Hsf. Against bacterial strains, such as E. coli, B. subtilis, and S. aureus, MICs were significantly low ranging from 0.0625-1.000 and $0.5-19 \mu \mathrm{g} / \mathrm{mL}$. In 2015, P. Arthi and coworkers reported a series of pendant-armed Schiff base hexaaza macrocycles manganese(II) complexes by the condensation of equimolar amounts of terephthalaldehyde and $\mathrm{N}, \mathrm{N}$-bis(2-aminoethyl)benzamide derivatives in the presence of $\mathrm{Mn}\left(\mathrm{ClO}_{4}\right)_{2} \cdot 6 \mathrm{H}_{2} \mathrm{O}$ as a templating agent (15, Figure 3) [55]. In comparison to the standard drug, ciprofloxacin, the complexes showed good activities against both Gram-negative (K. pneumoniae, P. aeruginosa, V. alginolyticus, V. cholerae and $V$. harveyi) and Gram-positive (S. aureus and S. mutans) bacterial strains. The mean zone of inhibition values of the complexes and the standard were in the range of 4-21 and 20-25 mm $(100 \mu \mathrm{g} / \mathrm{mL})$, respectively. Also in 2015, Simpson et al. described the antibacterial and antiparasitic activities of manganese(I) tricarbonyl complexes with ketoconazole, miconazole, and clotrimazole ligands [56]. The molecules were tested against eight different bacterial strains: Gram-positive, such as S. aureus, S. epidermidis, E. faekalis, and E. faecium, and Gram-negative, such as E. coli, P. aeruginosa, Y. pseudotuberculosa, and Y. pestis. Only the miconazole complex (MIC values of 10-20 $\mu \mathrm{M}$ on E. coli, Y. pseudotuberculosa, and Y. pestis) was active against Gram-negative bacteria 
and showed higher activity than miconazole alone. Conversely, all species were active against Gram-positive bacteria at submicromolar concentrations (MIC $=0.625$ to $2.5 \mu \mathrm{M}$ ), particularly against staphylococci. The complexation of luteolin to manganese(II) was carried out to prepare manganese(IV) complex 16, (Figure 3) [57]. The ligand and complex were screened against different microbial strains (e.g., E. coli, S. aureus, L. monocytogenes and P. aeruginosa) and $\mathbf{1 6}$ was found $\sim \mathrm{x} 1.5$ more active than the ligand alone. A study on a series of manganese(I) tricarbonyl complexes bearing bis(2-pyridinylmethyl)(2-quinolinylmethyl)amine, bis(2-quinolinylmethyl)(2-pyridinylmethyl)amine, tris(2-quinolinylmethyl)amine, and tris(2-pyridinylmethyl)amine ligands (17, Figure 3), was reported recently by Güntzel and coworkers [58]. The compounds were examined against 14 different multidrug-resistant clinical isolates of $A$. baumannii and $P$. aeruginosa showing MIC values in the range of $0.2-0.8 \mathrm{mM}$. Finally, Kottelat et al. described a series of carbonyl complexes of manganese bearing isocyanide ligands of formula $f a c-\left[\mathrm{Mn}(\mathrm{CO})_{3}(\mathrm{CNR})_{2} \mathrm{Br}\right]$ and found that for $\mathrm{CNR}=$ (1-isocyanoethyl)benzene, the complex showed a MIC of $128 \mu \mathrm{g} / \mathrm{mL}$ against E. coli [59]. Several other manganese metal complexes have been recently tested for their antimicrobial efficacy but were not found to be active [60-63].<smiles>CCn1cc(C(=O)O)c(=O)c2cc3c(cc21)OCO3</smiles>

Hoxo<smiles></smiles>

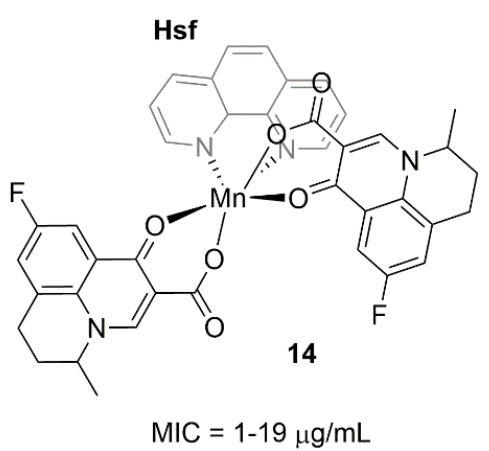

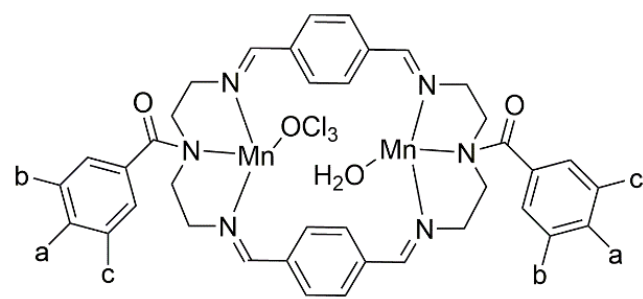

15

a, b, c $=\mathrm{H}$ or $\mathrm{NO}_{2}$

$100 \mu \mathrm{g} / \mathrm{mL}$ IZD $=4-21 \mathrm{~mm}$<smiles>[Y19]Oc1cc(O)cc2c(O[W])c(-c3ccc(O)c(O)c3)oc(=O)c12</smiles><smiles>CC1CCc2cc(F)cc3c(=O)c(C(=O)O)cn1c23</smiles>

Hflmq

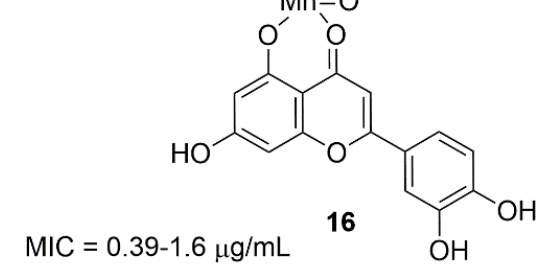

$M I C=0.39-1.6 \mu \mathrm{g} / \mathrm{mL}$

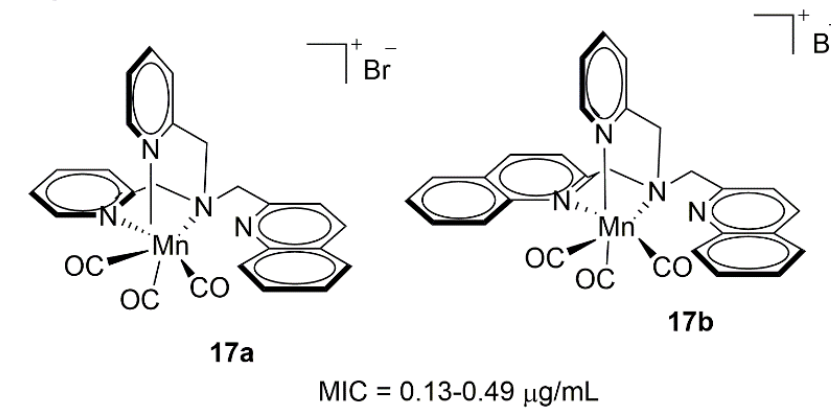

Figure 3. Structural formula of selected manganese(I), (II) and (IV) complexes and antibacterial drugs oxalinic acid (Hoxo), enrofloxacin (Herox), sparfloxacin (Hsf) and flumequine (Hflmq). 


\subsection{Manganese Photoactivatable CO-Releasing Molecules (PhotoCORMs)}

PhotoCORMs are a special class of manganese-based antimicrobial complexes (Figure 4). The molecules are able to release carbon monoxide when activated with light. Carbon monoxide then acts in concert with the metal fragment to impart antimicrobial efficacy to the species. The $\left[\mathrm{Mn}(\mathrm{CO})_{3}\left(\mathrm{tpa}-\mathrm{k}^{3} \mathrm{~N}\right)\right] \mathrm{Br}$ complex $(\mathbf{1 8}$, Figure 4) was the first one reported in the literature and it remains the most extensively studied [64-67]. It was active against several E. coli strains (K12 derivative MG1655, EC958, APEC), if photo-activated and perturbs the growth of multidrug-resistant isolates of Avian Pathogenic E. coli (APEC) (both in vitro and in vivo) without the need of light activation. In vivo (G. mellonella wax moth model), $\mathbf{1 8}$ showed no toxicity at double the concentration required in the treatment assay. The complex 19 (known as Trypto-CORM), was described in 2014 by Ward et al. [68,69]. The compound was not toxic to eukaryotic RAW264.7 cells but showed a strong antibacterial effect against E. coli strain W3110, N. gonorrhoeae and S. aureus. It completely inhibited E. coli growth following irradiation, leading to a loss of $>99.9 \%$ of cell viability. Trypto-CORM was similarly toxic to $N$. gonorrhoeae, in the dark resulting in a loss of $>99 \%$ cellular viability (half maximal inhibitory concentration $\left(\mathrm{IC}_{50}\right)$ value of $22 \mu \mathrm{M}$ ). Furthermore, complex 19 exhibited a cytostatic effect in the dark and cytotoxic effect if exposed to light against $S$. aureus. Mann et al. introduced molecule 20 and studied the broad-spectrum antimicrobial potential of the molecules $[70,71]$. The complex 20 inhibited growth of E. coli and several antibiotic resistant clinical isolates of pathogenic bacteria in a concentration-dependent manner. It extensively concentrated in E. coli cells, reaching concentrations of $\sim 3.5 \mathrm{mM}$ after $80 \mathrm{~min}$ of incubation. Significantly, 20 was effective against several pathogens isolated from clinical infections and causes in vitro a complete growth arrest of the multidrug-resistant $E$. coli EC958 clinical pathogen, K. pneumoniae, S. flexneri, S. kedougou and E. hormaechei, but it was ineffective against growth of $P$. aeruginosa, $C$. koseri, and A. baumannii.

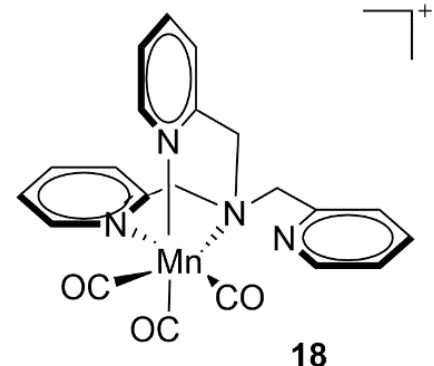

$\mathrm{MIC}=262-524.1 \mu \mathrm{g} / \mathrm{mL}$

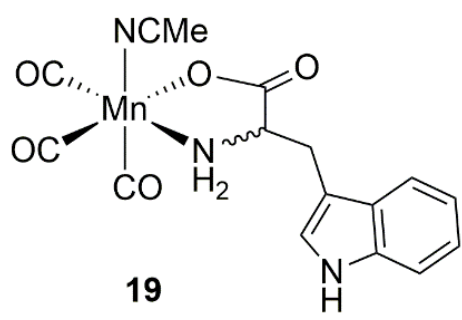

$\mathrm{MIC}=38.3 \mu \mathrm{g} / \mathrm{mL}$<smiles></smiles>

20

Figure 4. Structural formula of selected antimicrobial manganese(I) photoactivatable CO-releasing molecules.

\subsection{Rhenium Complexes}

In 2014, Noor et al. described a family of bioconjugated tridentate pyridyl-1,2,3-triazole macrocycles and the corresponding rhenium(I) complexes (21, Figure 5), which were screened for antimicrobial activities in vitro against both Gram-positive (S. aureus) and Gram-negative (E. coli) bacterial strains [72]. The minimum inhibitory concentrations for the compounds, however, showed values $>256 \mu \mathrm{g} / \mathrm{mL}$. At the same time Partra and coworkers introduced an interesting trimetallic complex (22, Figure 5) containing a ferrocenyl $(\mathrm{Fc})$, a cymantrene and a $\left[(\mathrm{dpa}) \operatorname{Re}(\mathrm{CO})_{\mathrm{s}}\right]$ residue (dpa $=N, N$-bis(pyridine-2-ylmethyl)prop-2-yn-1-amine) as the main biological active moiety of the construct [73]. A systematic structure-activity relationship (SAR) study against various Gram-positive pathogenic bacteria, including methicillin-resistant $S$. aureus (MRSA) strains proved that $\left[(\mathrm{dpa}) \operatorname{Re}(\mathrm{CO})_{3}\right]$ moiety was the essential part for the antibacterial activity of the trimetallic complex. The other two metallic units ( $\mathrm{Fc}$ and cymantrene) could be replaced by organic compounds without affecting the 
antibacterial activities of the construct. The MIC values of the compounds against Gram-positive bacterial strains, such as B. subtilis, S. aureus DSM 20231 and S. aureus ATCC43300 (MRSA) were found in the range of 1.4-21 $\mu \mathrm{M}$. In 2016, Kumar et al. [74] reported a group of mono- and bis-fac-rhenium tricarbonyl 2-pyridyl-1,2,3-triazole complexes with different aliphatic and aromatic substituents (23, Figure 5) which were tested for antimicrobial activities in vitro against both Gram-positive (S. aureus) and Gram-negative (E. coli) bacterial strains. The MICs for all the complexes were measured between 16 and $1024 \mu \mathrm{g} / \mathrm{mL}$. In 2017, a family of $\mathrm{N}$-heterocyclic carbene (NHC) fac-[Re(I)(CO) 3 ] complexes containing unsubstituted benzimidazol-2-ylidene and bisimine ligands $\left(\mathrm{N}^{\wedge} \mathrm{N}\right)$ ligands (24, Figure 5), were reported by Siegmund et al. [75]. The antimicrobial tests gave MIC values of the complexes between $0.7-2 \mu \mathrm{g} / \mathrm{mL}$ against Gram-positive strains, such as B. subtilits and S. aureus. However, the same complexes were inactive against Gram-negative strains, such as E. coli, A. baumannii and P. aeruginosa. Recently, Frei et al. reported the synthesis and antibacterial profiling of three rhenium bisquinoline complexes (25, Figure 5) [76]. The complexes displayed light-induced activities against drug-resistant S. aureus and E. coli showed MICs under photo-irradiation between 4- to 16-fold lower than in the dark. Other rhenium metal complexes have been tested for their antimicrobial efficacy but were inactive [77-80].<smiles>[R]c1cn(Cc2cc(OCc3ccccn3)cc(OCc3cn(Cc4cccc(Cn5cc(Cn6cc(C(C)(Br)Br)nn6)nn5)n4)nn3)c2)nn1</smiles>

$M=f a c-\left[\operatorname{Re}(\mathrm{CO})_{3}\right]^{+}$

$\mathrm{MIC}>256 \mu \mathrm{g} / \mathrm{mL}$

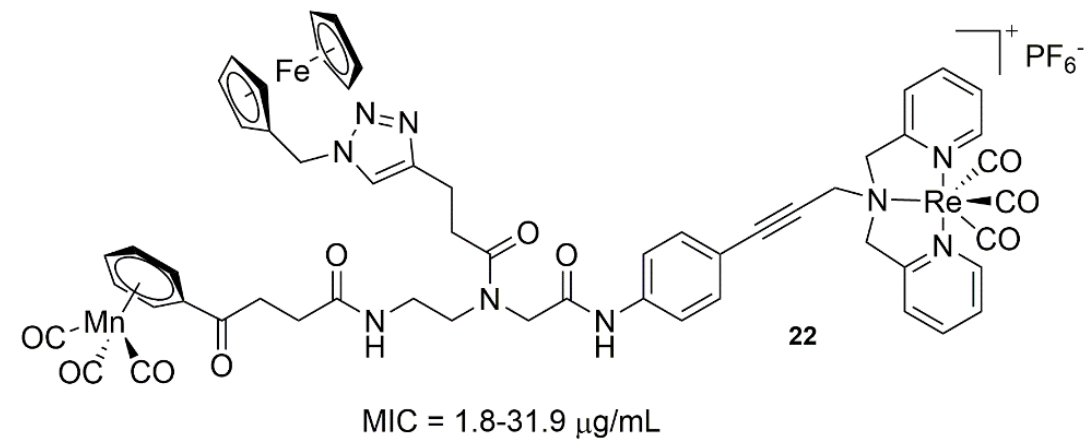

$\mathrm{MIC}=1.8-31.9 \mu \mathrm{g} / \mathrm{mL}$

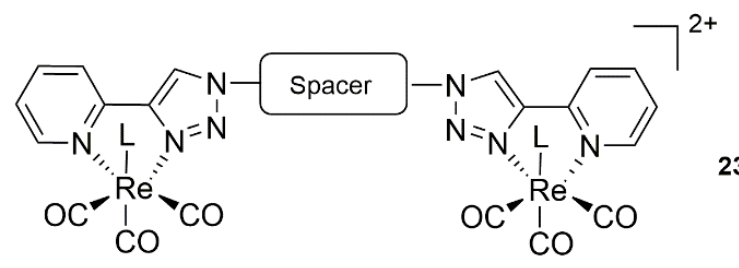

$\mathrm{MIC}=16-1024 \mu \mathrm{g} / \mathrm{mL}$

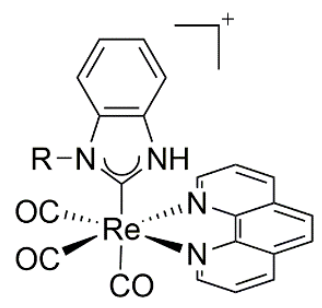

24

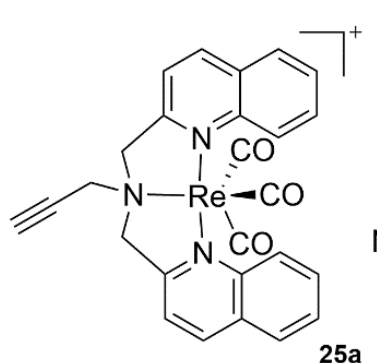

25a

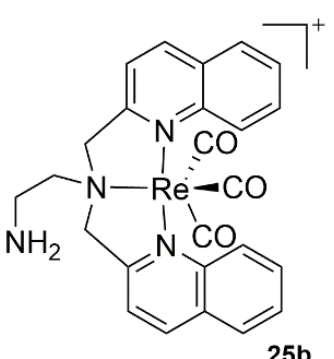

25b

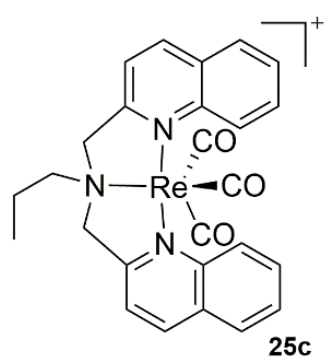

$\mathrm{MIC}=0.7-2.0 \mu \mathrm{g} / \mathrm{mL}$

$$
\begin{aligned}
\mathrm{MIC}_{\text {dark }}=1-32 \mu \mathrm{g} / \mathrm{mL} \\
\mathrm{MIC}_{\text {light }}=0.25-8 \mu \mathrm{g} / \mathrm{mL}
\end{aligned}
$$

Figure 5. Structural formula of selected antimicrobial rhenium(I) complexes. 


\section{Group 8}

\subsection{Ruthenium Complexes}

As stated in the introduction, iron complexes are not treated in this review; however, before discussing Ru species, the helicates-chiral assemblies reported by Howson et al. in 2012 deserves a special mention for their unique structure [81]. The species (26, Figure 6) were prepared by alkylation of 2 equiv. of (R)-2-phenylglycinol with 1 equiv. of $\alpha, \alpha^{\prime}$-dibromo-p-xylene followed by reaction with 2-pyridinecarboxaldehyde and $\mathrm{Fe}\left(\mathrm{ClO}_{4}\right)_{2} \cdot 6 \mathrm{H}_{2} \mathrm{O}$ in the proportions 3:6:2. Single bimetallic diastereomerically pure flexicates $\Delta_{\mathrm{Fe}}, R_{\mathrm{C}^{-}}\left[\mathrm{Fe}_{2} \mathrm{~L}_{3}\right]\left[\mathrm{ClO}_{4}\right]_{4}$ were isolated following heating of the mixture at $85{ }^{\circ} \mathrm{C}$ for $24 \mathrm{~h}$. These flexicates showed good antibacterial activities against MRSA and E. coli with MIC values in the $4-8 \mu \mathrm{g} / \mathrm{mL}$ range.

Ruthenium, as the second member of group 8 transition metals, has appeared in many reports as the central metal ion of new potential antimicrobial agents [82-93]. Here we describe the latest examples, but a recent perspective offers more details on the subject [10]. In 2016, Kumar and coworkers reported a series of tris(homoleptic) ruthenium(II) complexes with 2-(1- $R-1 H-1,2,3-$ triazol-4-yl)pyridine ligands (R-pytri) containing different aliphatic and aromatic substituents (27, Figure 7) [94]. The in vitro antimicrobial activities of R-pytri ligands and their mer- and fac- $\left[\mathrm{Ru}(\mathrm{R} \text {-pytri })_{3}\right]^{2+}$ complexes were screened against both Gram-positive (S. aureus, S. pyogenes and MRSA) and Gram-negative (A. calcoaceticus) bacterial strains. The experiments resulted in the good activity of two $\left[\mathrm{Ru}(\mathrm{R}-\mathrm{pytri})_{3}\right]^{2+}$ complexes (where $\mathrm{R}=$ hexyl or octyl) against Gram-positive bacteria with MIC values between 1 and $8 \mu \mathrm{g} / \mathrm{mL}$ (depending on the strain), but lower activity was seen against Gram-negative A. calcoaceticus $(\mathrm{MIC}=16-128 \mu \mathrm{g} / \mathrm{mL})$. More importantly, both complexes showed stronger antibacterial effects $(\mathrm{MIC}=4-8 \mu \mathrm{g} / \mathrm{mL})$ than gentamicin as the control $(\mathrm{MIC}=16 \mu \mathrm{g} / \mathrm{mL})$ against two strains of MRSA (MR 4393 and MR 4549). Liao et al. have reported a study involving octahedral ruthenium(II) complexes as antimicrobial agents against the mycobacterium $M$. smegmatis [95]. The complex 28 (Figure 7) selectively inhibited $M$. smegmatis growth with MIC of $2 \mu \mathrm{g} / \mathrm{mL}$ comparable to those of norfloxacin and rifampicin (MIC of 2 and $1 \mu \mathrm{g} / \mathrm{mL}$, respectively). All complexes, however, were found to be inactive against S. aureus (MSSA), P. aeruginosa, E. coli, C. albicans and C. neoformans.

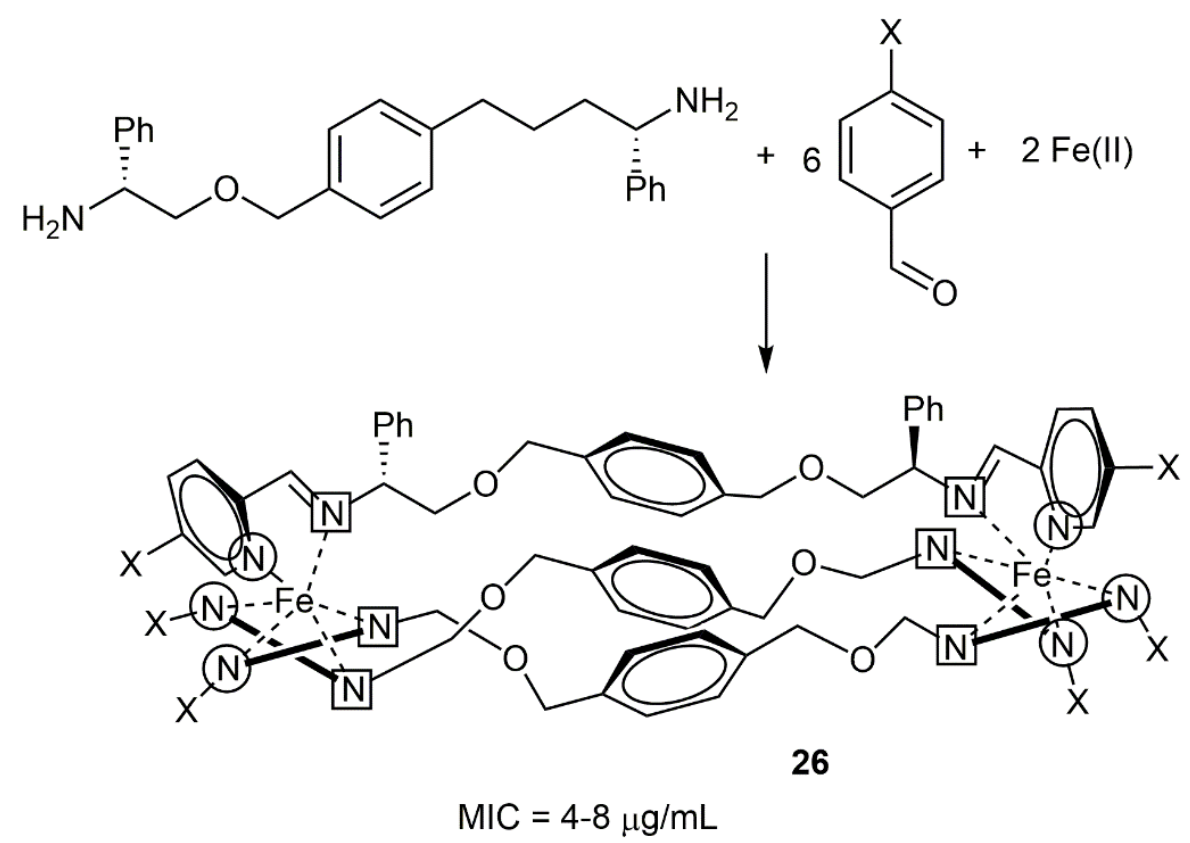

Figure 6. Structural formula of antimicrobial iron(II) flexicates. 

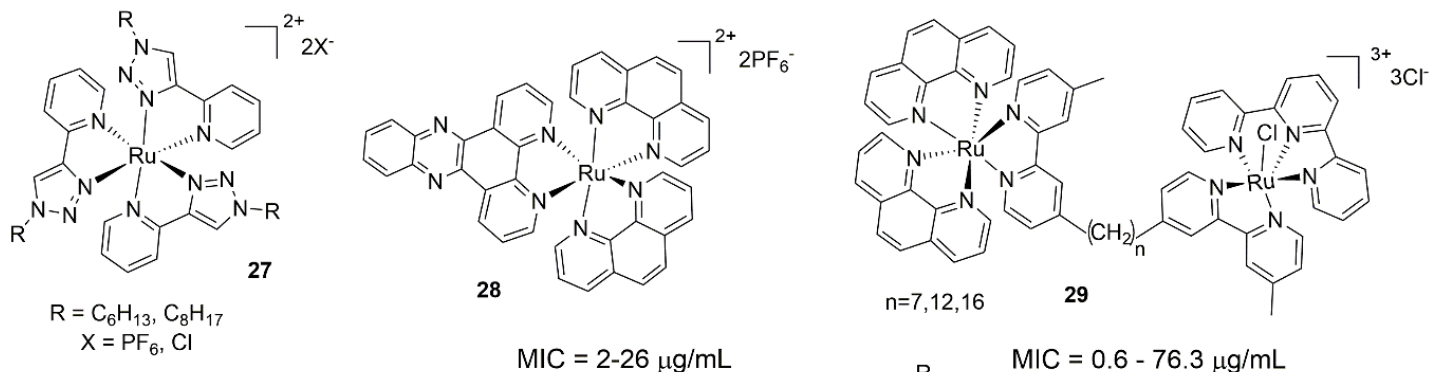

$\mathrm{MIC}=1-128 \mu \mathrm{g} / \mathrm{mL}$

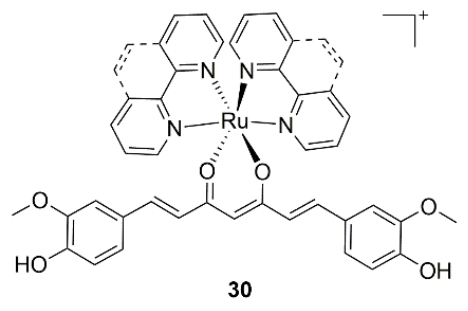

$\mathrm{MIC}=1 \mu \mathrm{g} / \mathrm{mL}$

$\mathrm{MIC}=2-26 \mu \mathrm{g} / \mathrm{mL}$

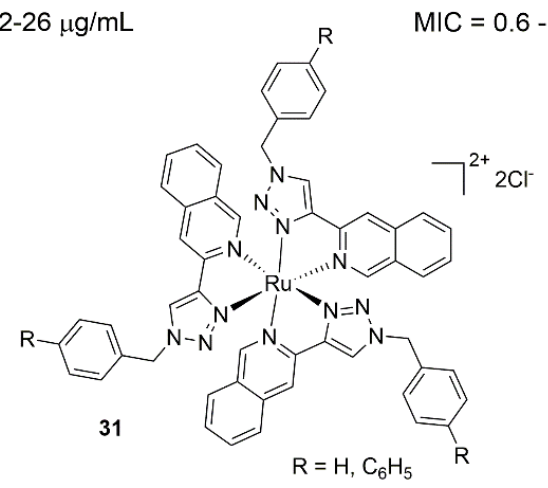

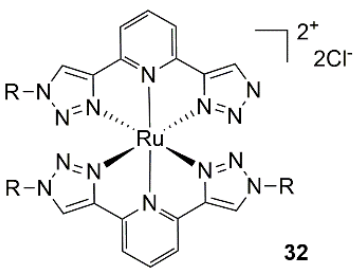

$R=$ aliphatic chain $\mathrm{C}_{n} \mathrm{H}_{2 n+1}$ with $n=3-9$

$\mathrm{MIC}=2-64 \mu \mathrm{g} / \mathrm{mL}$

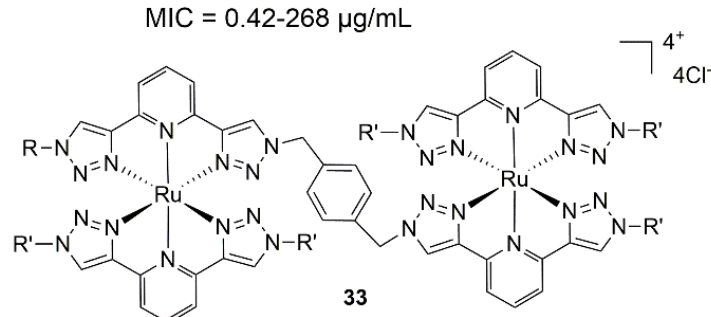

dihexylditripy: $\mathrm{R}=\mathrm{C}_{6} \mathrm{H}_{13}$ diheptylditripy: $\mathrm{R}^{\prime}=\mathrm{C}_{7} \mathrm{H}_{15}$

$\mathrm{MIC}=4-10 \mu \mathrm{g} / \mathrm{mL}$

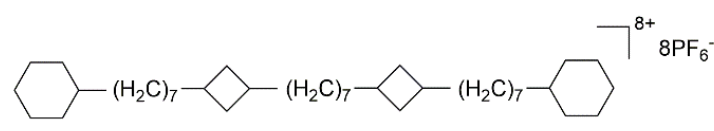

34

$\mathrm{MIC}=2-32 \mu \mathrm{g} / \mathrm{mL}$

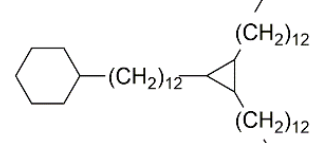

35

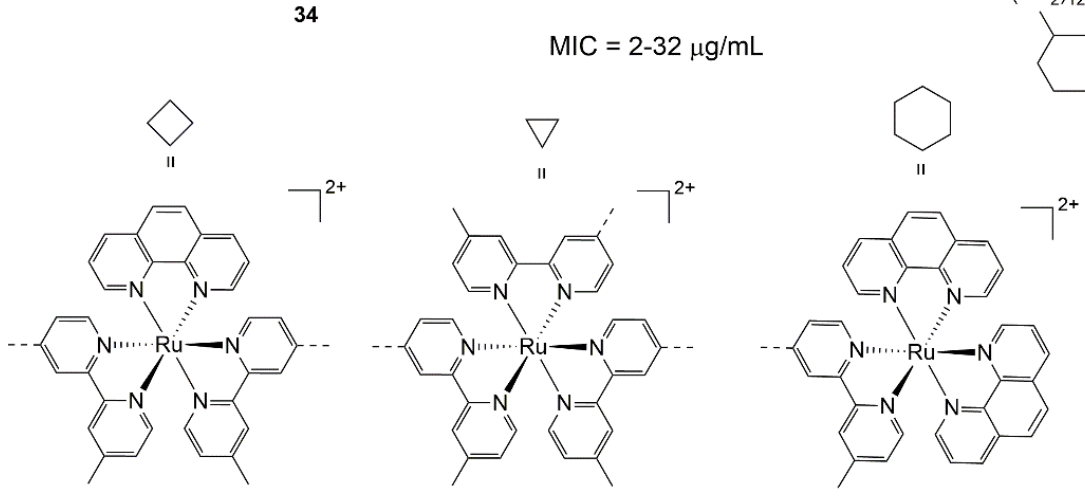

Figure 7. Structural formula of selected antimicrobial ruthenium(II) complexes.

In a study published in 2016 [96], Li et al. introduced a series of non-symmetric dinuclear polypyridylruthenium(II) complexes (29, Figure 7), and tested the same as antimicrobial agents. These complexes contained one inert metal center and one coordinatively-labile metal center, linked via the bis[4(4'-methyl-2,2'-bipyridyl)]-1,n-alkane ligand. The ruthenium(II) complexes were tested against four strains of bacteria, S. aureus and MRSA (Gram-positive), and E. coli and P. aeruginosa 
(Gram-negative). In most cases, the compounds showed good MIC values (0.6-0.7 $\mu \mathrm{M}$, comparable to gentamicin) against MRSA, they were less effective against $E$. coli and nearly inactive against P. aeruginosa. More recently, Srivastava et al. reported ruthenium(II) polypyridyl complexes [97] coordinated to curcumin, $\left[\mathrm{Ru}(\mathrm{NN})_{2}(\mathrm{cur})\right]\left(\mathrm{PF}_{6}\right)[\mathrm{NN}=$ bpy, phen], (30, Figure 7) and tested them against a panel of ESKAPE pathogens, including the drug resistant $S$. aureus ATCC. The results revealed a good inhibitory effect of the complexes against the latter pathogen and a remarkably high selectivity index (MIC $=1 \mu \mathrm{g} / \mathrm{mL}$ vs 0.25 for levofloxacin, SI = 80). Also in 2019, ruthenium(II) complexes of bidentate chelators 1-(1-benzyl-1,2,3-triazol-4-yl)isoquinoline and 3-(1-benzyl-1,2,3-triazol-4-yl)isoquinoline (31, Figure 7) were reported by Kreofsky et al. [98]. The complexes were screened against Grampositive bacteria (e.g., B. subtilis and S. epidermidis), and revealed a very low MIC value of $0.4 \mu \mathrm{M}$. In the same year, van Hilst et al. described mono and dinuclear ruthenium(II) complexes of 2,6-bis(1-R-1,2,3-triazol-4-yl)pyridine ligands (32 and 33, Figure 7), bearing aliphatic substituents [99]. The antibacterial activities of the complexes were evaluated by in vitro tests against $S$. aureus, and $E$. coli strains. The MIC values for the most active mononuclear complex, $[R u(h e x y l t r i p y)(h e p t y l t r i p y)]^{2+}$ (i.e., 33 with $\mathrm{n}=7$ in Figure 7), were $2 \mu \mathrm{g} / \mathrm{mL}$ and $8 \mu \mathrm{g} / \mathrm{mL}$, against $S$. aureus and E. coli, respectively. $[\mathrm{Ru} \text { (hexyltripy)(heptyltripy) }]^{2+}$ and $\left[\mathrm{Ru}_{2} \text { (dihexylditripy)(hexyltripy) }\right]^{4+}$ also showed good activities against the Gram positive and Gram negative methicillin resistant $S$. aureus strains (MICs $=4-8 \mu \mathrm{g} / \mathrm{mL}$ and $8-16 \mu \mathrm{g} / \mathrm{mL}$, respectively). Finally, linear (34) and non-linear (35) tetranuclear ruthenium(II) complexes were reported by Sun and coworkers [100], as having MIC values against six strains of bacteria (Gram-positive S. aureus and MRSA; Gram-negative, E. coli strains MG1655, APEC, UPEC and P. aeruginosa) in the range between 2 and $32 \mu \mathrm{g} / \mathrm{mL}$.

\subsection{Osmium Complexes}

There are only a few reports that have appeared lately detailing antimicrobial studies of osmium complexes. In 2015, a series of enantiopure $(S, S)$-iPr-pybox and $\{(S, S)$-iPr-pybox $=2,6$ bis[4(S)-isopropyloxazolin-2-yl]pyridine\} osmium(II) complexes (36, Figure 8), were prepared by Menéndez-Pedregal and coworkers [101]. The complexes were screened against M. luteus, B. subtilis, E. coli, S. coelicolor, S. antibioticus, and P. aeruginosa bacteria. The results showed inhibition halos $(\mathrm{mm})$ of the complexes in the range of $6-20 \mathrm{~mm}$ at concentrations between 99 and $500 \mu \mathrm{g} / \mathrm{mL}$. Gichumbi and coworkers reported a class of osmium(II)-arene complexes with bidentate $N, N^{\prime}$-ligands (37, Figure 8) [102]. A panel of antimicrobial-susceptible and -resistant Gram-negative (E. coli, K. pneumonia and P. aeruginosa) and Gram-positive (B. subtilis, E. faecalis, S. aureus, S. aureus, S. saprophyticus and M. smegmatis) bacterial strains were used to examine the antimicrobial activities of the synthesized complexes. The results showed promising anti-mycobacterial activity against M. smegmatis, and bactericidal activity against drug-resistant E. faecalis and methicillin-resistant S. aureus ATCC 43300.

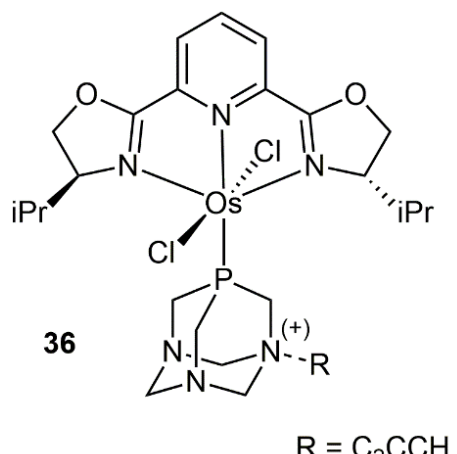

$99-190 \mu \mathrm{g} / \mathrm{disk}$ IZD $=8-19 \mathrm{~mm}$<smiles></smiles>

$800 \mu \mathrm{g} / \mathrm{mL}$ IZD $=12-21 \mathrm{~mm}$

Figure 8. Structural formula of selected antimicrobial osmium(II) complexes. 


\section{Group 9}

\subsection{Cobalt Complexes}

In 2010, Zhu et al. reported azide bridged Schiff bases 5-methoxy-2-[(2-morpholin-4-ylethylimino) methyl]phenol and 2-ethoxy-6-[(2-isopropylaminoethylimino)methyl]phenol cobalt(III) complexes (38 and 39, Figure 9) [103], and tested them against a panel of pathogens. The complexes 38 and 39 were active against $B$. subtilis, E. coli and S. aureus with the MIC values in the range of $4-18.5 \mu \mathrm{g} / \mathrm{mL}$, but less active against $P$. fluorescens with MIC values of 21.7 and $37.3 \mu \mathrm{g} / \mathrm{mL}$, respectively. The authors explained the bactericidal mechanism of action of the metal complexes by Overtone's concept [104] and Tweedy's chelation theory [105]. Coordination to the metal ion of the chelating Schiff bases results in the overlap of the ligand orbital and partial sharing of the positive charge of the ion with donor groups, which gives rise to a decrease in the polarity of the metal ion. As a result, the delocalization of $\pi$-electrons over the whole chelate ring increases and, consequently, enhances the lipophilicity of the complex. The main effect of increased lipophilicity is that of improving complexes penetration through lipid membranes, and finally, deactivation of the binding sites on enzymes of microorganisms.

Irgi et al. reported in 2015 a study of the antimicrobial potential of cobalt(II) complexes featuring coordination to the quinolone oxolinic acid drug (Hoxo), and 2,2'-bipyridine (bipy), 2,2'bipyridylamine (bipyam), 1,10-phenanthroline (phen), pyridine (py) or 4-benzylpyridine (4bzpy) ligands (40, Figure 9) [106]. The antimicrobial activities of Hoxo and its complexes were screened against Gram-negative (E. coli NCTC 29212 and X. campestris ATCC 1395), and Gram-positive (S. aureus ATCC 6538 and B. subtilis ATCC 6633) bacterial species. Oxolinic acid and its cobalt(II) complexes showed inhibitory action against all the microorganisms tested, with MIC values in the $1-2 \mu \mathrm{g} / \mathrm{mL}$ range for most of the complexes. Similar cobalt(II) complexes, based on a series of coordinated quinolone sparfloxacin and nitrogen-donor heterocyclic ligands bipy, phen or 2,2'-bipyridylamine (bipyam) (41, Figure 9), were introduced in 2016 by Kouris et al. [107]. The ligand and complexes showed remarkable antimicrobial activities against bacteria strains, such as X. campestris, S. aureus, B. subtilis and E. coli with MICs of $0.031-0.500 \mu \mathrm{g} / \mathrm{mL}$. The authors suggested that the chelate effect and the presence of sparfloxacinato and $\mathrm{N}$-donor ligands, as well as the generation of the quinolone ligand, could be the prevailing factors contributing to the antimicrobial activities of the complexes.

A class of $\left[\mathrm{CoCl}_{2}(\text { dap })_{2}\right] \mathrm{Cl}$ (dap = 1,3-diaminopropane) and $\left[\mathrm{CoCl}_{2}(\mathrm{en})_{2}\right] \mathrm{Cl}$ (en = ethylenediamine) were recently reported by Turecka et al. [108], and tested against a broad spectrum of reference and clinical fungal strains of Candida. The complexes showed MICs of $\sim 16 \mu \mathrm{g} / \mathrm{mL}$ on the selected species (e.g., C. glabrata ATCC 2001) but were not as effective as amphotericin B and ketoconazole. A series of zinc(II), copper(II) and cobalt(II) metallophthalocyanine (Pc) compounds derivatized with four 2-methoxy-4-\{(Z)-[(4-morpholin-4-ylphenyl)imino]methyl $\}$ phenol at the peripheral positions (42, Figure 9) were reported by Unluer et al. [109]. According to the in vitro studies, cobalt(II)Pc and copper(II)Pc complexes, in particular, showed antibacterial activities against S. typhimurium and E. coli. Recently, a series of 2-formylpyridine 4-allyl-S-methylisothiosemicarbazone of zinc(II), copper(II), nickel(II) and cobalt(III) complexes were reported [110]. The in vitro tests showed that cobalt(III) complexes (43, Figure 9) were more active against Gram-positive bacteria (e.g., S. aureus) and fungal strains (C. albicans) with MIC values of $0.7-3$ and $7-250 \mu \mathrm{g} / \mathrm{mL}$, respectively, and less active against Gram-negative strains, such as E. coli and K. pneumoniae. Several other types of cobalt metal complexes have been tested for their antimicrobial efficacy, however, their activities were not found remarkably high [111-121]. 


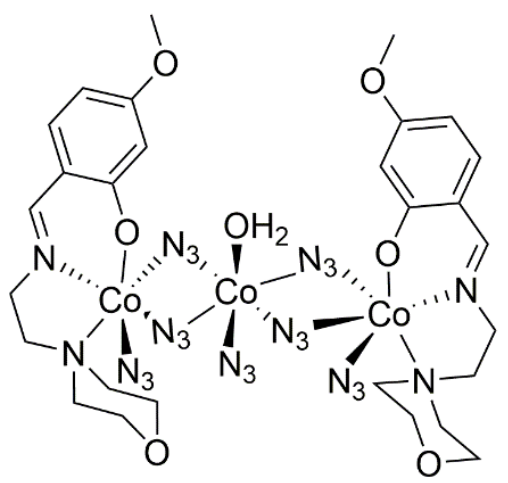

38

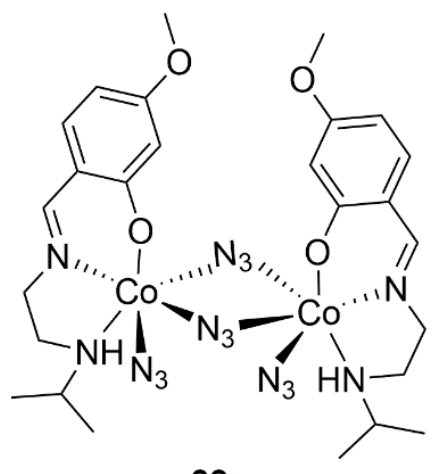

39

$\mathrm{MIC}=4.0-18.5 \mu \mathrm{g} / \mathrm{mL}$
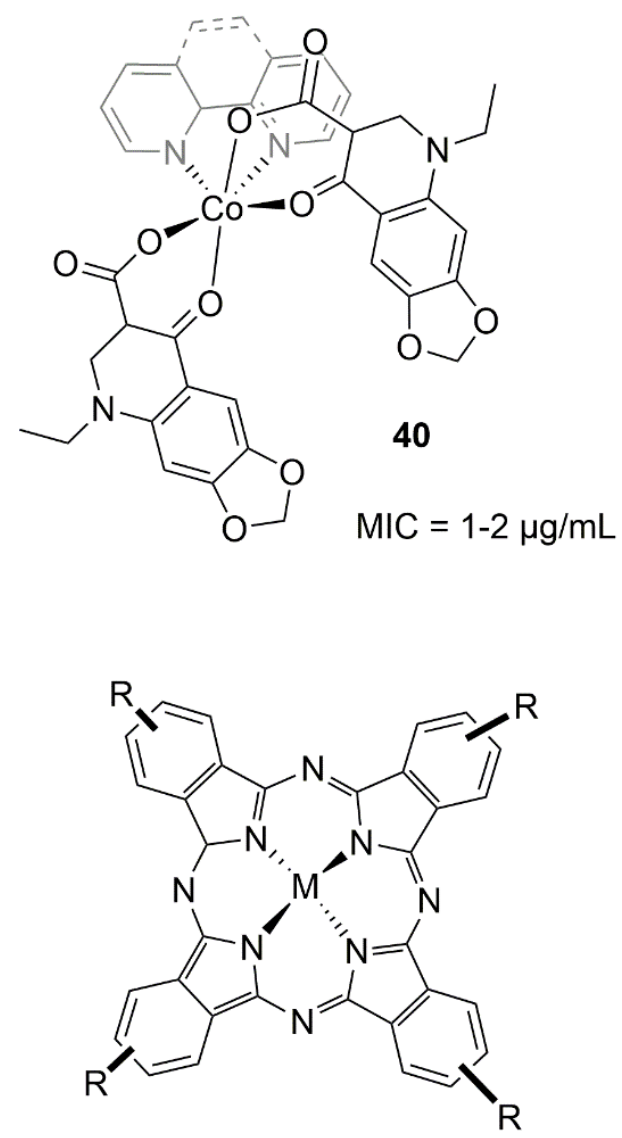

$\mathrm{M}=\mathrm{Zn}(\mathrm{II}), \mathrm{Cu}(\mathrm{II}), \mathrm{Co}(\mathrm{II})$<smiles></smiles>

42
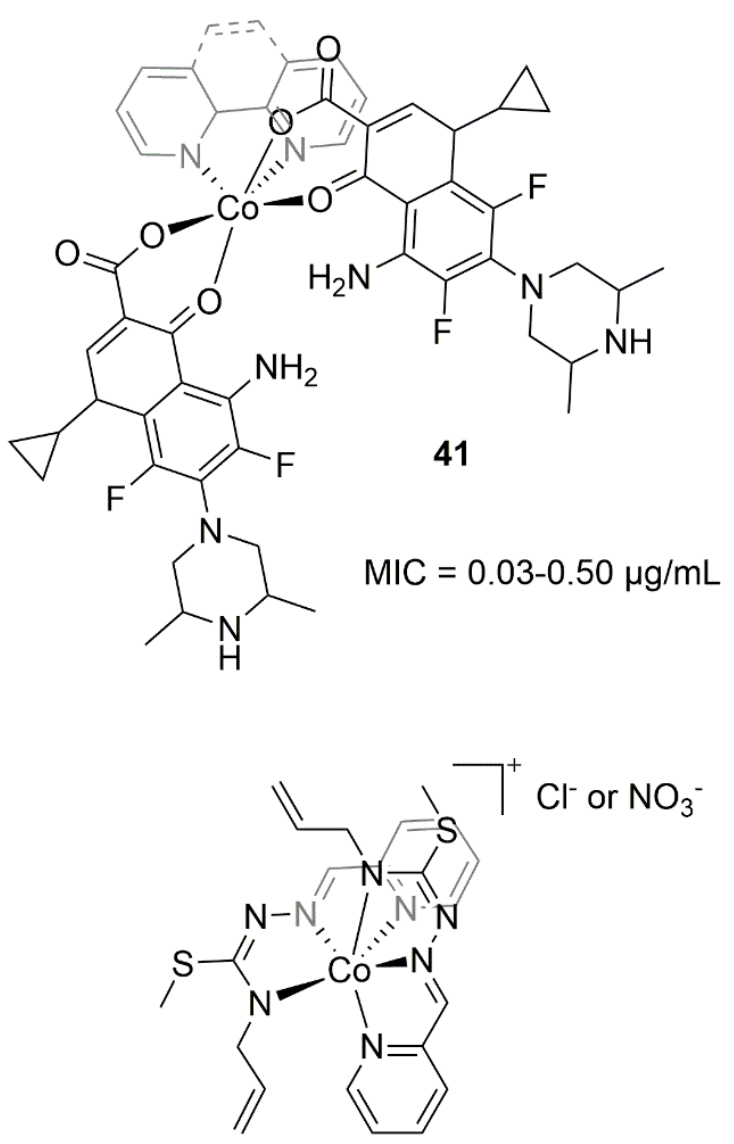

43

$\mathrm{MIC}=0.7-250 \mu \mathrm{g} / \mathrm{mL}$

$\mathrm{MIC}=1.25-625 \mu \mathrm{g} / \mathrm{mL}$

Figure 9. Structural formula of selected antimicrobial cobalt(II) and cobalt(III) complexes and corresponding ligands. 


\subsection{Rhodium and Iridium Complexes}

Rhodium and iridium complexes hold great potential as metal-based antimicrobial agents. In 2015, Lu et al. tested a series of cyclometallated rhodium(III) and iridium(III) complexes for their antimicrobial activities [122]. The in vitro tests revealed that complex 44 (Figure 10) had a selective inhibitory effect against $S$. aureus growth with MIC and MBC values of 3.60 and $7.19 \mu \mathrm{M}$, respectively. The complex was the first example of a substitutionally-inert, group 9 organometallic compound utilized as a direct inhibitor of S. aureus. In 2017, Fiorini et al. [123] reported methylation of iridium(III) tetrazolato complexes as an effective route to modulate the emission outputs and to switch the antimicrobial properties of the species. Transformation of neutral iridium(III) tetrazolato complexes 45 to the equivalent methylated cations 46 (Figure 10), was accompanied by a remarkable change in the antimicrobial activities of the complexes. Compounds of general structure 45 were inactive against Gram-negative (E. coli) and Gram-positive (D. radiodurans) microorganisms. However, by converting them to methylated cationic derivatives 46 , the MIC values of the latter dropped to $1-4 \mu \mathrm{g} / \mathrm{mL}$ against the $D$. radiodurans bacterial strain. The same year, Kumar et al. prepared an iridium(III) complex of formula $\left[\operatorname{Ir}(\operatorname{cod})(\mathrm{dmtu})_{2}\right] \mathrm{Cl}$ (where $\operatorname{cod}=1,5$-cyclooctadiene and dmtu $=N, N^{\prime}$-dimethylthiourea, 47 in Figure 10), from the reaction of dmtu with the $[\operatorname{Ir}(\operatorname{cod})(\mathrm{Cl})]_{2}$ dimer [124]. The antimicrobial activity of the complex was investigated against E. coli, S. aureus and P. aeruginosa, and it showed good activity against the two latter strains. In 2018, DuChane and coworkers reported a series of $\sim 40$ rhodium(III) and iridium(III) half-sandwich complexes of formula $\left[\left(\eta^{5}-\mathrm{Cp} * \mathrm{R}\right) \mathrm{M}(\beta\right.$-diketonato $\left.) \mathrm{Cl}\right]$ $(\mathrm{M}=\mathrm{Rh}(\mathrm{III}), \mathrm{Ir}(\mathrm{III}), 48$ in Figure 10) [125] and tested them against M. smegmatis. The rhodium(III) complexes were found consistently more active than the iridium analogs with MIC values in the range of 2-16 $\mu \mathrm{M}$ and $15-69 \mu \mathrm{M}$ for the two ions, respectively. The most active rhodium(III) complex was the one bearing pentamethylcyclopentadiene $\left(\eta^{5}-\mathrm{Cp}^{*} \mathrm{R}\right.$ where $\left.\mathrm{R}=-\mathrm{CH}_{3}\right)$ and dipivaloylmethane as the $\beta$-diketonato chelate.

Recently, Lapasam and coworkers have reported a family of mononuclear metal complexes containing hydrazone ligands (L) of the type [(arene)MLCl $]^{+}(\mathrm{M}=\mathrm{Ru}(\mathrm{II}), \mathrm{Rh}(\mathrm{III})$ and $\mathrm{Ir}(\mathrm{III}), 49 \mathrm{in}$ Figure 10) [126]. The antibacterial efficacies of the complexes were evaluated against four pathogenic bacteria, such as S. aureus, E. coli, B. thuringiensis and P. aeruginosa. All the complexes behaved selectively against $P$. aeruginosa and $B$. thuringiensis with comparable activities to gentamycin but were inactive against E. coli and S. aureus. In a report in 2019, the same author described related ruthenium(II), rhodium(III) and iridium(III) arene complexes bearing pyridyl azine Schiff base ligands (50 and 51, Figure 10) showing potent antibacterial activities against S. aureus, E. coli and K. pneumonia with the zone of inhibition (at conc. $2.0 \mathrm{mg} / \mathrm{mL}$ ) greater than that of ciprofloxacin [127]. A class of neutral heteroleptic cyclometalated iridium(III) complexes linked to boron dipyrromethene (BODIPY) substituted $\mathrm{N}$-heterocyclic carbene (NHC) ligands was characterized by Liu et al. in 2019 [128]. The antimicrobial photo-biological properties of 52 and 53 (Figure 10) were evaluated against S. aureus bacteria growing as planktonic cultures. The results revealed good activity of $\mathbf{5 3}$ against the pathogen upon visible light activation, with a phototherapeutic index $>15$ and the half-maximal effective concentration $\left(\mathrm{EC}_{50}\right)$ value of $6.67 \mu \mathrm{M}$.

In 2018, a series of organoiridium(III) antimicrobial complexes containing biguanides derivatives as chelated ligands were reported by Chen et al. (54, Figure 10) [129]. The compounds have remarkable activities against both Gram-negative and Gram-positive bacteria, including MRSA with MICs as low as $0.125 \mu \mathrm{g} / \mathrm{mL}$. The complexes also exhibited a high fungicidal effect toward C. albicans and C. neoformans with MIC values of $0.25 \mu \mathrm{g} / \mathrm{mL}(0.34 \mu \mathrm{M})$, and generally, low cytotoxicity toward mammalian cells. In 2019, DuChane et al. evaluated a series of piano-stool iridium complexes with 1,2-diaminoethane ligands against bacterial strains of $S$. aureus, including various isolates of methicillin-resistant strains (MRSA) [130]. The in vitro tests indicated an interesting difference between stereoisomers of the species with complex 55 (cis isomer, Figure 10) being the most effective compound with MIC values of 5 and $7.5 \mu \mathrm{g} / \mathrm{mL}$ against $S$. aureus and MRSA, respectively. Recently, Lapasam et al. introduced a series of ruthenium(II), rhodium(III) and iridium(III) complexes with 4-phenyl-1-(pyridin-4yl)methylene 
thiosemicarbazide and 4-phenyl-1-(pyridin-4yl)ethylidene thiosemicarbazide ligands (56, Figure 10) with comparable antibacterial properties to that of ciprofloxacin [131]. The MIC values of the complexes were as low as $0.015 \mathrm{mg} / \mathrm{mL}$ (MIC of ciprofloxacin $=0.031-0.062 \mathrm{mg} / \mathrm{mL}$ ) against S. aureus, E. Coli and K. pneumonia.

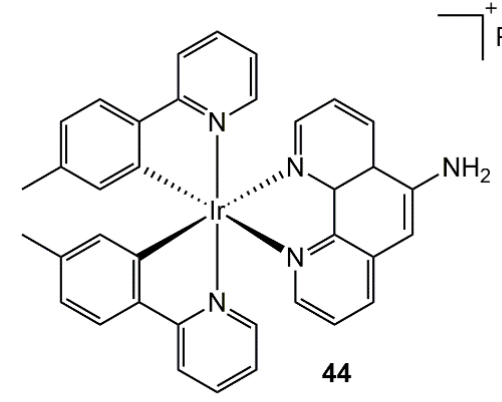

$\mathrm{MIC}=3.3-6.6 \mu \mathrm{g} / \mathrm{mL}$

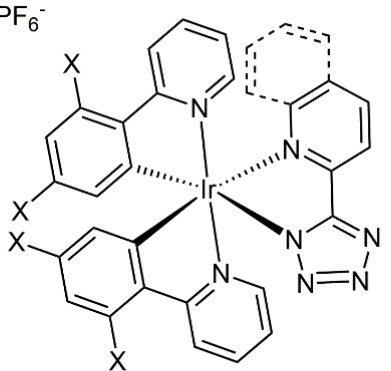

45

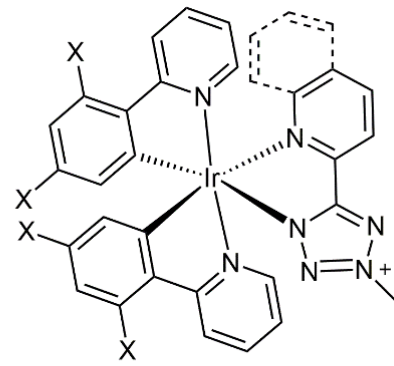

46

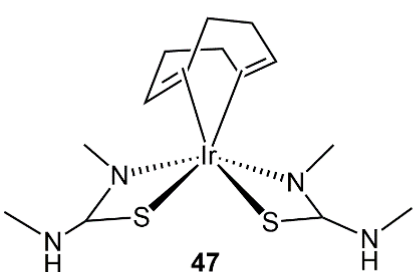

47

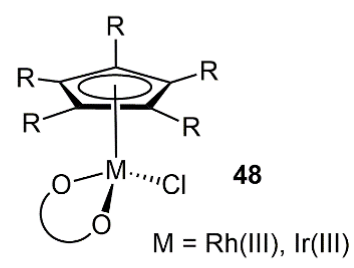

$\mathrm{MIC}=8.41-40.1 \mu \mathrm{g} / \mathrm{mL}$

$5000 \mu \mathrm{g} / \mathrm{mL}$
$I Z D=7-10 \mathrm{~mm}$

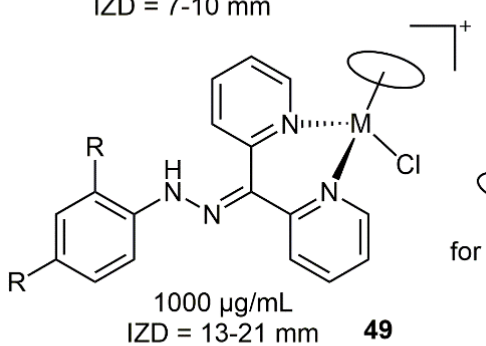<smiles>Cc1ccc(C(C)C)cc1</smiles>
for 49-51

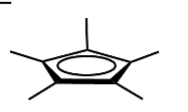
$M=\operatorname{Rh}(I I I), \operatorname{Ir}(I I I)$<smiles>C/C(=N\C=C\C(Cl)(Cl)n1ccc(Cl)c1)NN</smiles><smiles>C/N=C\C=[Ru][Mg]</smiles>
$\mathrm{H}_{2} \mathrm{~N}^{\prime}$

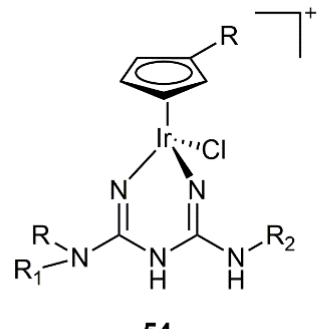

54

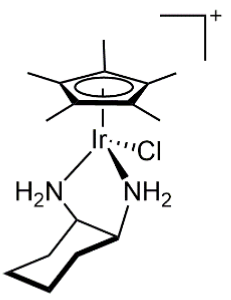

55

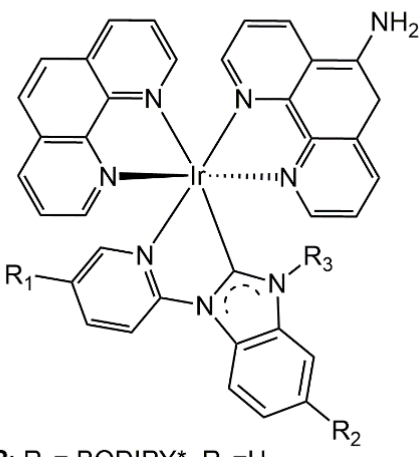

52: $\mathrm{R}_{1}=$ BODIPY $^{*}, \mathrm{R}_{2}=\mathrm{H}$,

$\mathrm{R}_{3}=2$-[2-methoxyethoxy)ethoxy]ethyl 53: $\mathrm{R}_{1}=\mathrm{H}, \mathrm{R}_{2}=$ BODIPY*,

$R_{3}=$-[2-(methoxyethoxy)ethoxy]ethyl

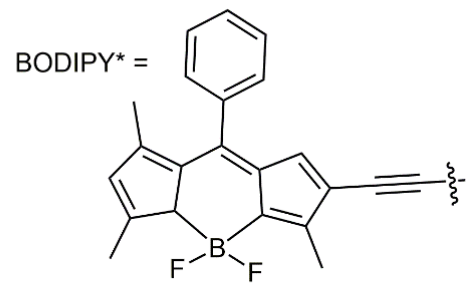

$\mathbf{5 2}_{\text {vis }}: \mathrm{EC}_{50}>125.4 \mu \mathrm{g} / \mathrm{mL}$ $53_{\text {vis }}: \mathrm{EC}_{50}=8.3 \mu \mathrm{g} / \mathrm{mL}$

$\mathrm{MIC}=0.12-0.25 \mu \mathrm{g} / \mathrm{mL} \quad \mathrm{MIC}=5-7.5 \mu \mathrm{g} / \mathrm{mL}$

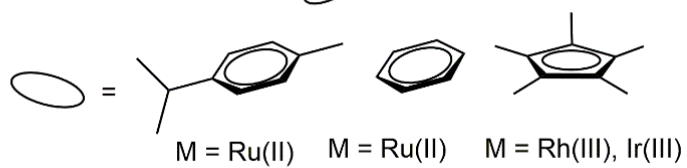

$\mathrm{MIC}=150 \mu \mathrm{g} / \mathrm{mL}$

Figure 10. Structural formula of selected antimicrobial rhodium(III) and iridium(III) complexes. $\mathrm{EC}_{50}=$ half-maximal effective concentration. 


\section{Group 10}

\subsection{Nickel Complexes}

Group 10 antimicrobial complexes are not as active as metal complexes of other groups and generally show relatively high MICs when compared to other transition metal species. Nickel is no exception. Therefore, only two selected cases will be given in the current section. In 2017, Raj et al. described Schiff base (57, Figure 11) nickel(II) complexes with MIC values against $S$. aureus $(15-30 \mu \mathrm{g} / \mathrm{mL})$ comparable to the standard drug, ciprofloxacin [132]. The complexes, whose structures remained undefined, also showed good MICs against methicillin resistant S. aureus (MRSA, 20-50 $\mu \mathrm{g} / \mathrm{mL}$ ), but were inactive against other tested pathogens (e.g., S. flexneri MTCC-1457, P. aeruginosa MTCC-741, and E. coli MTCC-119) and several fungal strains. The complexes exert their antimicrobial action by disintegrating the bacterial cell membrane. Recently, Ibrahim et al. [133] presented nickel(II) complexes of NNS tridentate thiosemicarbazone based ligands (58, Figure 11) and evaluated them against several bacterial (e.g., E. coli, P. aeruginosa, B. cereus, S. aureus, M. luteus and S. marcescens) and fungal (e.g., F. oxysporum, C. albicans, G. candidum, A. flavus, S. brevicaulis and T. rubrum) strains. The complexes all showed similar and comparable effects as the standard antibacterial chloramphenicol drug. The results varied in terms of the antifungal potency of complexes 58, but the active ones showed greater inhibition than clotrimazole (the standard drug).

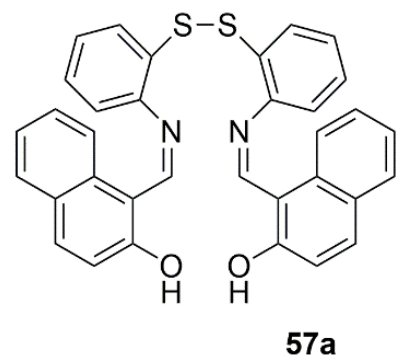

$\mathrm{MIC}=15-30 \mu \mathrm{g} / \mathrm{mL}$<smiles>Oc1cccc(/C=N\c2ccccc2SSc2ccccc2/C=N/c2cccc(O)c2O)c1O</smiles>

$57 b$<smiles>[R]c1ccccc1NC1=NN(Cl)c2cccnc2N1C</smiles>

as $1 \% \mathrm{w} / \mathrm{v}$ DMSO solutions IZD = 6-17 mm

Figure 11. Structural formula of Schiff base ligands $57 \mathrm{a}$ and $57 \mathrm{~b}$ and nickel(II) antimicrobial complex 58.

\subsection{Palladium and Platinum Complexes}

Several palladium and platinum complexes have been tested for their antimicrobial potencies and a few species showed significant effects. In general, the reported complexes of the two metal ions were not as effective as those of other metals and palladium compounds were more active than the platinum ones. It is, however, instructive to also overview some of the latest reported examples not showing antimicrobial potential. By varying reaction conditions and stoichiometry of reagents, Juribašić et al. [134] prepared a series of quinolinylaminophosphonate palladium(II) halide complexes (59-61, Figure 12) and tested them on a wide spectrum of bacterial and fungal strains. None of the species was active. Similarly, the methylpyrazole-4-carboxaldehyde thiosemicarbazone and the 2-((6-allylidene-2-hydroxycyclohexa-1,3-dienylmethylene)amino)benzoic acid complexes (62 and 63, Figure 12) were inactive [135]. Radić et al. introduced $S$-alkyl thiosalicylic acid derivatives of palladium(II) (64, Figure 12) and investigated the antimicrobial potential of the ligands and complexes on a wide panel of 26 microorganism species [136]. The palladium(II) complexes were inactive against nearly all pathogens with the exception of fungal strains (e.g., A. fumigatus and A. flavus) with MICs $<7.8 \mu \mathrm{g} / \mathrm{mL}$. 
<smiles></smiles><smiles>[R]OP([R])(=O)C(Nc1ccccc1)c1nc2ccccc2cc1[X]</smiles>

59

59

60<smiles></smiles>

$\mathrm{R}=\mathrm{Et}, \mathrm{n}-\mathrm{Bu}$

$\mathrm{X}=\mathrm{Br}, \mathrm{Cl}$

MIC of 59-61 = ca. $200 \mu \mathrm{g} / \mathrm{mL}$

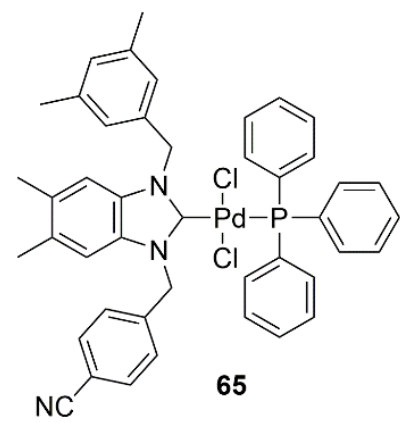

$M I C=18.6 \mu \mathrm{g} / \mathrm{mL}$

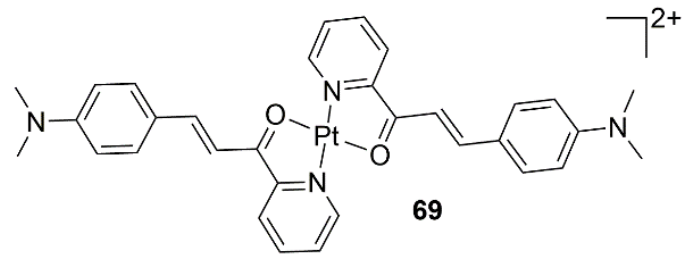

$\mathrm{MIC}=30000 \mu \mathrm{g} / \mathrm{mL}$

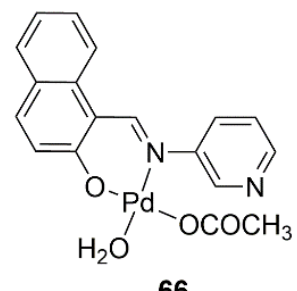

66

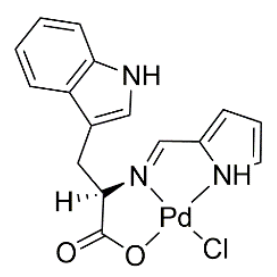

67

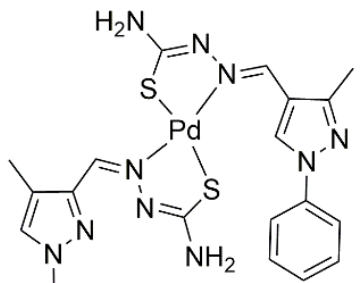

62

$\mathrm{MIC}=200 \mu \mathrm{g} / \mathrm{mL}$

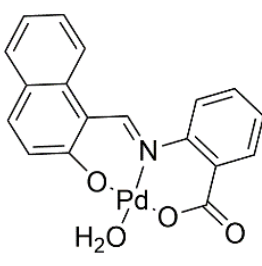

63

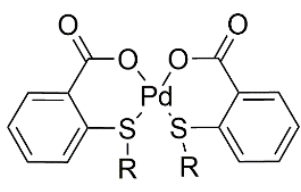

64
$\mathrm{MIC}<7.8 \mu \mathrm{g} / \mathrm{mL}$

$\mathrm{MIC}=2000 \mu \mathrm{g} / \mathrm{mL}$

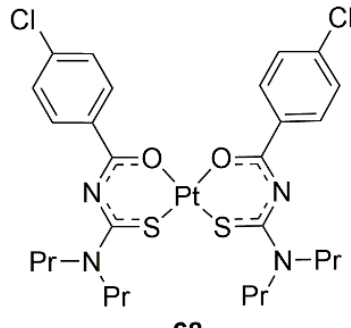

68

$\mathrm{MIC}=3.9 \mu \mathrm{g} / \mathrm{mL}$

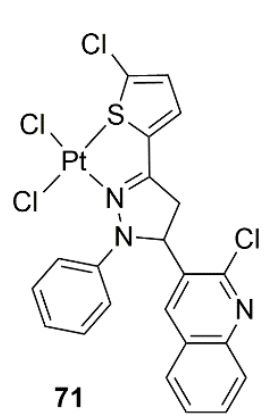

$M I C=16-32 \mu \mathrm{g} / \mathrm{mL}$

$M I C=26-35 \mu \mathrm{g} / \mathrm{mL}$

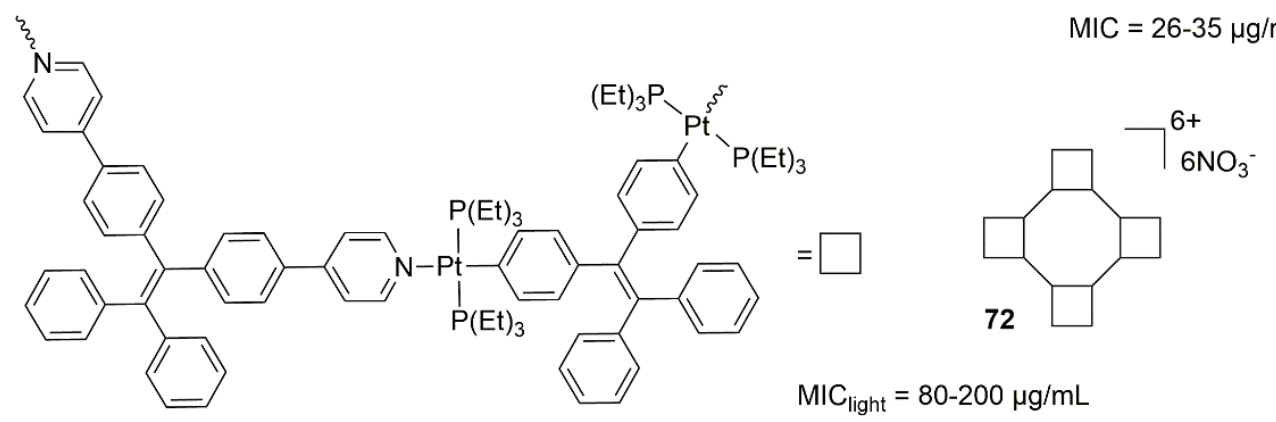

Figure 12. Structural formula of selected antimicrobial palladium(II) and platinum(II) complexes. 
In 2018, Boubakri et al., reported the synthesis and antibacterial properties of triphenylphosphine $\left(\mathrm{PPh}_{3}\right) \mathrm{N}$-heterocycle carbene (NHC) complexes of palladium(II) (65, Figure 12) [137]. The complexes were prepared by combining the $\mathrm{NHC}$ benzimidazolium salts with, $\mathrm{PdCl}_{2}, \mathrm{~K}_{2} \mathrm{CO}_{3}$ in pyridine at $80^{\circ} \mathrm{C}$, followed by reaction with triphenylphosphine. The in vitro tests of palladium(II)-NHC-PPh complexes against Gram-positive (M. luteus LB 14110, S. aureus ATCC 6538 and L. monocytogenes ATCC 19117) and Gram-negative (S. typhimurium ATCC14028 and P. aeruginosa ATCC 49189) pathogens showed moderate to significant activities of the complexes against the different bacterial strains. The MIC values against $M$. luteus, L. monocytogenes and S. typhimurium were in the range of $0.0197-0.625$, $0.078-1.25$, and $1.25-5 \mathrm{mg} / \mathrm{mL}$, respectively. A remarkable example of active palladium(II) complexes was obtained by Abu-Dief et al. [138]. The authors prepared a series of metal complexes bearing the 1-(pyridin-3-yliminomethyl)-naphthalen-2-ol ligand and tested the silver(I), palladium(II) and vanadium(II) oxide derivatives against different strains of bacteria and fungi (S. Marcescens, E. coli, M. Luteus F. oxysporum, G. candidum and A. flavus). The palladium(II) complex (66, Figure 12) showed MIC values against all tested strains between 1.50 and $3.00 \mu \mathrm{g} / \mathrm{mL}$, close to the standard drugs (ofloxacin and fluconazole). Recently, Nyawade et al. reported new 2-pyrral amino acid Schiff base palladium(II) complexes [139] and investigated their antibacterial effects against six species (Gram-positive, such as S. aureus, MRSA, S. epidermidis, S. pyogenes, and Gram-negative, such as P. aeruginosa and K. pneumonia). Of the series of compounds, complex 67 (Figure 12) was the most active showing comparable antimicrobial potency to ampicillin against MRSA, S. epidermidis and S. pyogenes.

Solmaz and coworkers synthesized $N, N$-Di-(R)- $N^{\prime}$-(4-chlorobenzoyl)thiourea platinum(II) complexes (68, Figure 12) and carried out antimicrobial tests against S. aureus, S. pneumonia, E. coli, P. aeruginosa, A. baumannii, C. albicans and C. glabrata [140]. The compounds were particularly effective against S. pneumonia, P. aeruginosa, and A. baumannii (MIC value of $3.90 \mu \mathrm{g} / \mathrm{mL}$ ) and moderately active against S. aureus, E. coli and C. albicans (MIC value of $15.62 \mu \mathrm{g} / \mathrm{mL}$ ). More recently, Gaber et al. reported palladium(II) and platinum(II) chalcone complexes of the bidentate ligand, (E)-3-(4-(dimethylamino)phenyl)-1-(pyridin-2-yl)prop-2-en-1-one (69, Figure 12) [141]. The platinum(II) complex showed low $\mathrm{IC}_{50}$ values but virtually no antimicrobial potency (MIC value of $\sim 30 \mathrm{mg} / \mathrm{mL}$ ) against $C$. albicans, A. flavus, E. coli or S. aureus. Palladium(II) and platinum(II) complexes with good antifungal activities against $C$. albicans and $C$. neoformans (MIC values of 32 and $16 \mu \mathrm{g} / \mathrm{mL}$, respectively for the two species) were those bearing a derivatized $N, N$-bidentate pyridyl benzimidazole ligand (70, Figure 12) reported by Mansour et al. [142]. In 2018, Lunagariya et al. tested square planar mononuclear platinum(II) complexes bearing 5-quinoline 1,3,5-tri-substituted pyrazole scaffolds against $S$. Aureus, B. subtilis, S. marcescens, P. aeruginosa and E. coli [143]. Within the series, compound 71 (Figure 12) showed good activity against the pathogens with MIC values between 25 and $35 \mu \mathrm{g} / \mathrm{mL}$. Finally, in 2019, Gao and coworkers published a bacterial membrane intercalation-enhanced photodynamic inactivation (PDI) system, of discrete organoplatinum(II) metallacycles (72, Figure 12) [144]. The compound acted as a photosensitizer with aggregation-induced emission. It self-assembled with a transacting activator of the transduction (TAT) peptide-decorated virus coat protein. The resulting aggregate intercalated in the bacterial cell membrane and decreased the survival rate of Gram-negative E. coli to nearly zero and that of Gram-positive S. aureus to $\sim 30 \%$ upon light irradiation. Several other complexes of these ions have been tested for their antimicrobial efficacy, however, their activities were not found remarkably high [145-169].

\section{Group 11}

\subsection{Copper Complexes}

In the last five years, hundreds of scientific publications have reported antimicrobial properties of copper complexes. As for iron and the other members of this group, the complexes of the metal ion would be best reviewed alone, but for completeness, a few recent selected examples will be mentioned in this section. In 2019, Kaushal et al. described the synthesis and characterization of 
several 2-acetylpyridine- $N$-substituted thiosemicarbazonates of copper(II) species (73, Figure 13) with remarkable antimicrobial activities against methicillin resistant $S$. aureus (MRSA), K. pneumoniae and C. albicans [170]. The complexes showed MICs values between 0.5 and $5 \mu \mathrm{g} / \mathrm{mL}$ and often equated the potency of amphotericin and gentamicin. The authors attempted a structure-activity relationship of the variation of antimicrobial bioactivity with variations of $R$ substituents and halogens $(X)$.

In general, for all pathogens, the halogens did not provide any preferential trend but variations occurred due to the substituents $\mathrm{R}$, with ethyl/methyl substituents showing high activity. Oladipo et al. reported a synthetic and structural study of copper(II) $N, N^{\prime}$-diarylformamidine dithiocarbamate complexes (74, Figure 13), showing excellent antibacterial activities against Gram-negative, S. typhimurium, P. aeruginosa, E. coli and K. pneumoniae and Gram-positive, S. aureus bacteria, including MRSA [171]. The MIC values of complexes were in the order of $6.25 \mathrm{ng} / \mathrm{mL}$ to $0.8 \mu \mathrm{g} / \mathrm{mL}$, surpassing in many cases the potency of ciprofloxacin. Krishnegowda and coworkers prepared 1-phenyl-1,3-butanedione copper(II) complexes (75, Figure 13), showing activity against B. cereus, Bacillus substilis, methicillin-resistant S. aureus, E. coli, P. aerogenes and K. pneumonia (MICs in the range of $10.4-16.5 \mu \mathrm{g} / \mathrm{mL}$ ) similar to ampicillin [172].<smiles></smiles>

73

$\mathrm{X}=\mathrm{Cl}, \mathrm{Br}, \mathrm{I}$ $\mathrm{R}=\mathrm{H}, \mathrm{Me}, \mathrm{Et}, \mathrm{Ph}$

$\mathrm{MIC}=0.5-5 \mu \mathrm{g} / \mathrm{mL}$

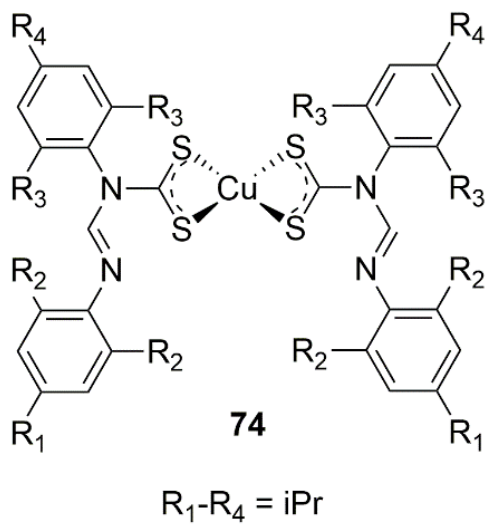

$\mathrm{MIC}=0.00625-0.8 \mu \mathrm{g} / \mathrm{mL}$

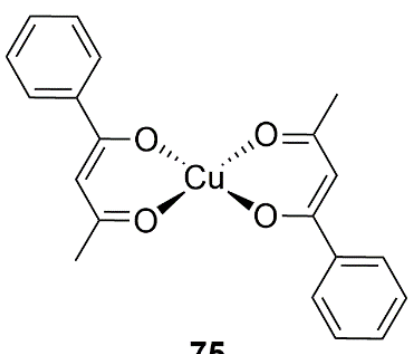

$\mathrm{MIC}=10.4-16.5 \mu \mathrm{g} / \mathrm{mL}$

Figure 13. Structural formula of selected antimicrobial copper(II) complexes.

\subsection{Gold Complexes}

Gold complexes have been investigated in a wide range of therapeutic applications (e.g., as antiarthritic agents for the treatment of rheumatoid arthritis and a variety of rheumatic diseases, including psoriatic arthritis, juvenile arthritis, palindromic rheumatism and discoid lupus erythematosus [173]), and continue to attract the attention of many organometallic chemists [174]. They also have great potential as antimicrobial agents. In this section, we have selected only a few examples, but a recent perspective offers more details on the subject [10].

In 2016, Savić et al. reported a series of aromatic nitrogen-containing heterocycles gold(III) species (76, Figure 14) in a comparative antimicrobial and toxicological study of gold and silver complexes of the same [175]. All square-planar gold complexes were evaluated in vitro against P. aeruginosa, E. coli, S. aureus, L. monocytogenes and C. albicans. They revealed good antibacterial activity with the MIC values in the 2.5 to $100 \mu \mathrm{g} / \mathrm{mL}$ range but were not as effective as the silver analogues. Hikisz et al. studied the antibacterial activities of the gold(I) alkynyl chromone complexes (77, Figure 14) against E. coli and Gram-positive methicillin-sensitive (MSSA) and methicillin-resistant (MRSA) S. aureus including clinical isolates [176]. In vitro tests of the complexes showed high activities against $S$. aureus pathogens with MICs between 2 and $32 \mu \mathrm{g} / \mathrm{mL}$, but they were not active against E. coli. Glišić et al. prepared dinuclear gold(III) complexes with bridging aromatic nitrogen-containing heterocyclic ligands (78, Figure 14) and studied their antimicrobial activities in relation to the complex nuclearity [174]. In most cases, complexes showed higher antibacterial activity than $\mathrm{K}\left[\mathrm{AuCl}_{4}\right]$ with MICs in the range of 3.9-62.5 $\mu \mathrm{g} / \mathrm{mL}$. The complexes 78 were particularly effective against $M$. luteus 
being $\sim 3 x$ more potent than kanamycin. In 2017, Schmidt and co-workers evaluated a series of gold(I) bis- $N$-heterocyclic carbene complexes (79, Figure 14) [177] for their effects against pathogenic bacteria E. faecium, E. coli, P. aeruginosa, A. baumannii, K. pneumonia and methicillin-resistant $S$. aureus strains (MRSA). The complexes showed good activity against MRSA (for $\mathrm{R}=\mathrm{Phe}, \mathrm{MIC}=1.7-2.3 \mu \mathrm{M}$ ) but were not as effective as auranofin or standard antibiotics. These biscarbene gold complexes act by inhibiting bacterial thioredoxin reductase (TrxRs) with moderate potency. Finally, Pöthig et al. recently described structurally interesting gold pillarplexes [178]. The compounds (80, Figure 14), however, showed little or no activity against $B$. subtilis, $S$. aureus, E. coli, P. aeruginosa or C. albicans.<smiles>[Y][X](Cl)(Cl)n1ccc[Y]1Cl</smiles>

$\mathrm{X}, \mathrm{Y}, \mathrm{Z}=$ either $\mathrm{C}$ or $\mathrm{N}$

$76 a$<smiles></smiles>

$76 b$

$\mathrm{MIC}=2.5-100 \mu \mathrm{g} / \mathrm{mL}$<smiles>[R3]c1ccc2oc([R])c([R])c(=O)c2c1</smiles><smiles>[R]c1oc2ccc(C#CC#[R16]c3ccccc3)cc2c(=O)c1[R]</smiles>

$M I C=2-32 \mu \mathrm{g} / \mathrm{mL}$<smiles></smiles>

$\mathrm{MIC}=3.9-62.5 \mu \mathrm{g} / \mathrm{mL}$<smiles></smiles>

$A: R=H$

$\mathrm{B}: \mathrm{R}=\mathrm{Br}$

C: $R=P h e$

$\mathrm{D}: \mathrm{R}=4-\mathrm{Br}-\mathrm{Phe}$

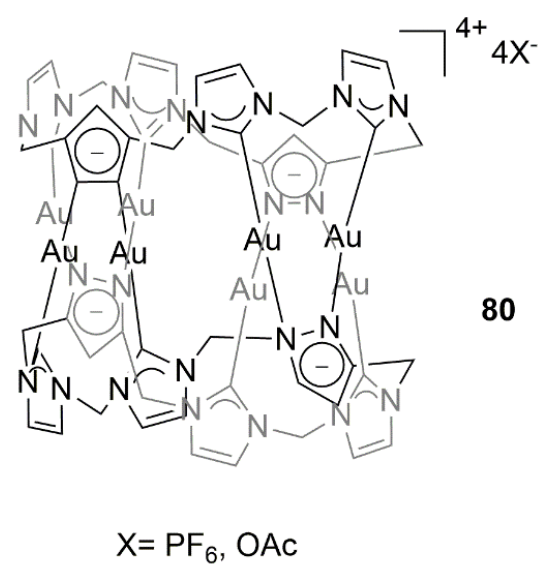

$M I C=1.5-61.5 \mu \mathrm{g} / \mathrm{mL}$

Figure 14. Structural formula of selected antimicrobial gold(I) and gold(III) complexes.

\section{Group 12}

\subsection{Zinc Complexes}

Zinc, the first element in group 12, is the only metal that appears in all enzyme classes [179-182]. Complexes of the element have been the topic of many studies, including antibacterial and antiviral activities [183]. In the last five years, more than 100 scientific publications on the antimicrobial properties of zinc complexes have been reported. As mentioned in Section 7, it is beyond the scope of this short review to detail all these studies. We have selected, therefore, only a few cases as interesting examples from the structural and chemical point of view.

In 2015, Zaltariov et al. reported zinc(II) complexes of trimethylsilyl-propyl-p-aminobenzoate (81, Figure 15) with remarkable antimicrobial properties [184]. The compounds showed the MIC values as low as $16 \mathrm{ng} / \mathrm{mL}$ against A. fumigatus, P. chrysogenum and Fusarium, and $0.38 \mu \mathrm{g} / \mathrm{mL}$ against Bacillus sp. and Pseudomonas sp., being more active than the standards, i.e., caspofungin and kanamycin. Abu Ali et al. investigated ibuprofen zinc(II) complexes in combination with mono and bidentate ligands such as 2-aminopyridine, 2-aminomethylpyridine and 2,2'-bipyridine (82 and 83, 
Figure 15) [185]. Compounds were screened against three Gram-positive (M. luteus, S. aureus and B. subtilis) and three Gram-negative (E. coli, K. pneumonia and P. mirabilis) bacterial strains. The complex containing ibuprofen and 2,2'-bipy (83, Figure 15) was the most potent compound against all bacteria with MICs of $\sim 1.5-3 \mathrm{mg} / \mathrm{mL}$. In 2018, Boughougal et al. reported a series of zinc(II) complexes coordinated to sulfadiazine and enrofloxacin (84, Figure 15) [186].

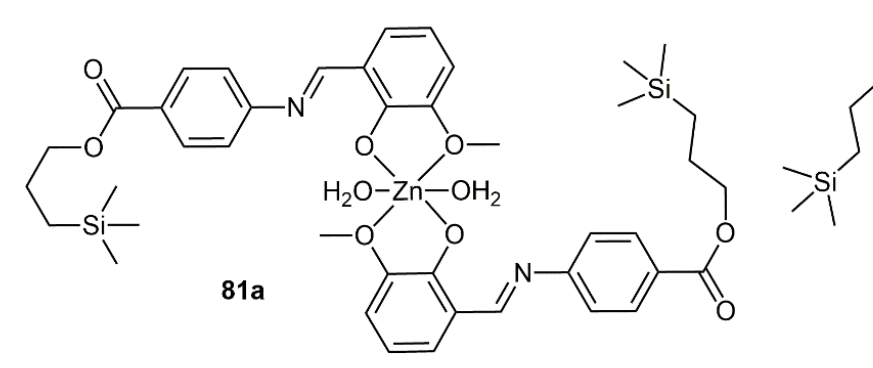

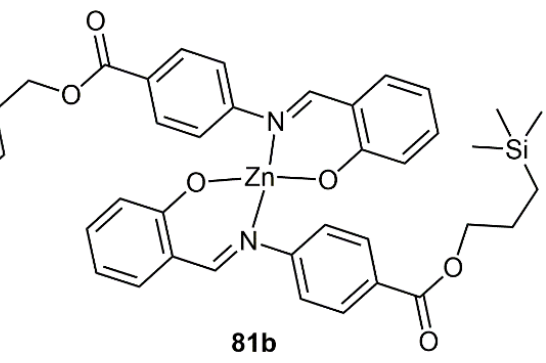

$\mathrm{MIC}=0.0016-0.38 \mu \mathrm{g} / \mathrm{mL}$<smiles></smiles><smiles></smiles>

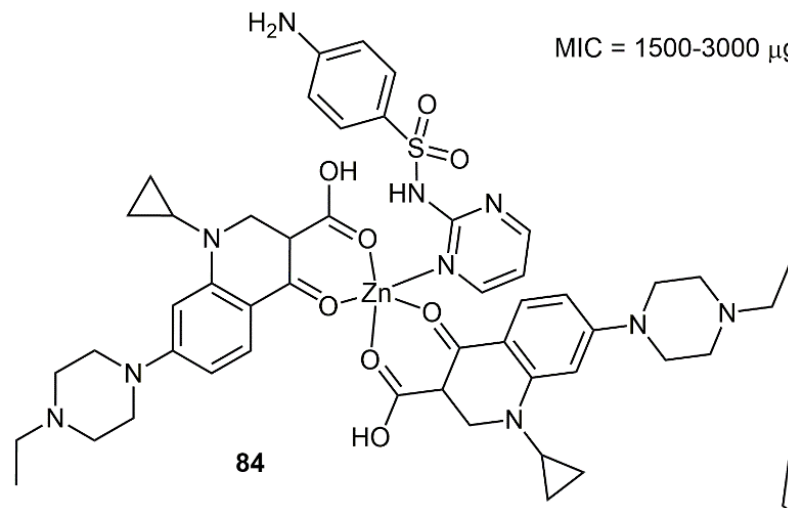

$\mathrm{MIC}=0.5 \mu \mathrm{g} / \mathrm{mL}$

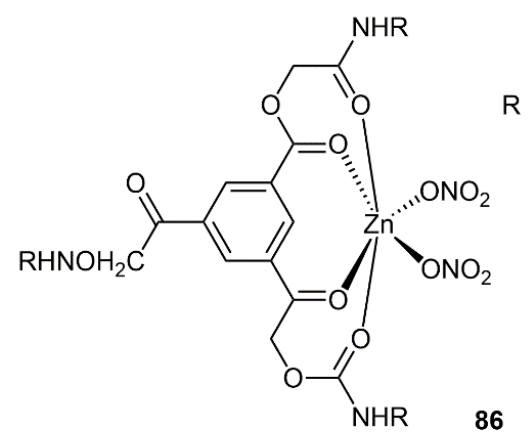

$\mathrm{MIC}=450 \mu \mathrm{g} / \mathrm{mL}$<smiles>[X]c1ccc(N)cc1</smiles><smiles>[R]c1ccnc(-c2cc([R])ccn2)c1</smiles>

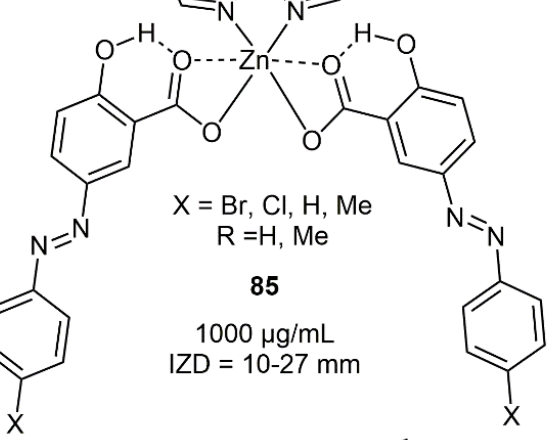

87

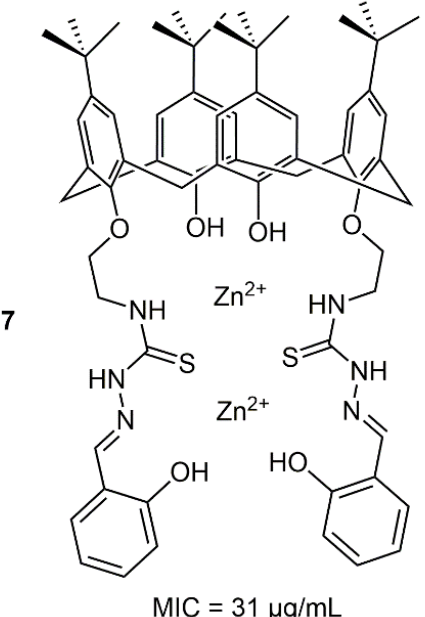

Figure 15. Structural formula of selected antimicrobial zinc(II) complexes. 
In all complexes, enrofloxacin acted as a bidentate ligand via the pyridinone and carboxylate oxygens. Free ligands and complexes showed good antibacterial activity against E. Coli, S. Aureus and E. Faecalis with MICs lower than $0.5 \mathrm{mg} / \mathrm{L}$. A series of zinc(II) compounds of aryl-substituted diazosalicylato- and pyridine ligands, was recently described by Basu Baul et al. (85, Figure 15) and tested along with copper and cadmium analogs against B. subtilis, S. aureus and K. pneumonia and C. albicans [187]. The zinc(II) complexes showed comparable activity to the standard chloramphenicol and fluconazole antimicrobial drugs. In 2019, Stataneva et al. described a new bioactive zinc(II) complex with a fluorescent symmetrical benzanthrone tripod for applications in antibacterial textiles (86, Figure 15) [188]. Tested against different pathogens, the complex showed the highest activity against $B$. cereus with a MIC of $450 \mu \mathrm{g} / \mathrm{mL}$. Recently, Noruzi et al. reported the biological activities of metal complexes of a multidentate calix[4]arene ligand doubly functionalized by 2-hydroxybenzeledene-thiosemicarbazone (87, Figure 15) [189]. Both the calix[4]arene ligand and its zinc(II) complex showed activity against B. subtilis, E. coli and P. aeruginosa with MICs of $31 \mu \mathrm{g} / \mathrm{mL}$.

\subsection{Cadmium and Mercury Complexes}

Several studies have described the antimicrobial properties of cadmium and mercury complexes since 2015. Despite the harmful nature of the metal ions and their complexes, they can still be remarkably useful for antimicrobial applications and they should not be neglected. However, given the inherent high toxicity associated with the metal ions, we decided to select only studies of complexes showing MICs in the low $\mu \mathrm{g} / \mathrm{mL} / \mu \mathrm{M}$ range and (where possible) with activities comparable to tested standard drugs. These stringent requirements considerably reduced the number of studies that we could consider here. Montazerozohori et al. have reported cadmium(II) and mercury(II) complexes of the bidentate Schiff base ligand 4-(3-(2-(4-(dimethyl aminophenyl alylidene aminopropylimino)prop-1-ethyl)- $N, N$-dimethyl benzene (88, Figure 16) and tested the molecules against two Gram-positive (B. substilis and S. aureus), and two Gram-negative (P. aeruginosa and E. coli) bacterial strains [190]. Mercury complexes with X = I and SCN showed minimum bactericidal concentration $(\mathrm{MBC})$ of 3.7 and $7.5 \mu \mathrm{g} / \mathrm{mL}$, respectively, against S. aureus and P. aeruginosa (SCN complex only). The cadmium complexes were less toxic, with the most active species $(X=S C N)$ showing a MIC of $25 \mu \mathrm{g} / \mathrm{mL}$ against $P$. aeruginosa. In 2016, Agertt et al. evaluated sulfonamide metal complexes of $\mathrm{Au}, \mathrm{Ag}, \mathrm{Cd}, \mathrm{Cu}$ and $\mathrm{Hg}$ for their antimycobacterial activities against $M$. abscessus, $M$. fortuitum and M. massiliense [191]. Cadmium and mercury complexes showed MICs of $4.9 \mu \mathrm{g} / \mathrm{mL}$ against M. fortuitum and M. massiliense and of 19.5 and $9.8 \mu \mathrm{g} / \mathrm{mL}$, respectively, against $M$. abscessus. It should be noted that the study did not report a full characterization of cadmium(II) and mercury(II) complexes and their structures are unknown. In a study published in 2019, Matiadis et al. investigated the antimicrobial properties of cadmium(II) metal complexes of the $\mathrm{N}$-acetyl-3-acetyl-5-benzylidenetetramic acid (89, Figure 16) [192]. The in vitro tests against five key "ESKAPE" pathogens (E. coli, MRSA, K. pneumoniae, A. baumannii and P. aeruginosa) and two fungi (C. neoformans and C. albicans) revealed that 89 was active only against $C$. neoformans (MIC $=8 \mu \mathrm{g} / \mathrm{mL}$ ).

In 2017 and 2018, Mandal et al. reported the synthesis, characterization and antimicrobial activities of cadmium(II) and mercury(II) complexes of 5-methyl pyrazole-3yl- $N$-(2'-methylthiophenyl) methyleneimine [193] and pyrazol-3-yl- $N$-(2-methoxyphenyl) methanimine [194] (90-93, Figure 16) against a panel of pathogens. In comparison to amoxicillin, cadmium(II) and mercury(II) complexes 90 and 92 showed very good antimicrobial activity against $P$. vulgaris and S. aureus with MICs of 35 and $25 \mu \mathrm{g} / \mathrm{mL}$ and 5 and $2 \mu \mathrm{g} / \mathrm{mL}$, respectively (MICs of amoxicillin $=129$ and $85 \mu \mathrm{g} / \mathrm{mL}$, respectively). Furthermore, $\mathbf{9 2}$ was 8 -fold more effective than amoxicillin against E. aerogenes (MIC of $92=35 \mu \mathrm{g} / \mathrm{mL}$ ) [193]. The complex 91 was inactive while 93 showed a MIC value of $10 \mu \mathrm{g} / \mathrm{mL}$ against different $V$. cholerae strains, P. aeruginosa and M. luteus [194]. Lam et al. have reported a series of bis-(alkynyl)mercury(II) complexes with oligothiophene and bithiazole linking units (94 and 95, Figure 16) with remarkable antimicrobial activity against MRSA and C. albicans [195]. Complex 94 showed the strongest bactericidal activity against MRSA with MIC and MBC values $0.2 \mu \mathrm{g} / \mathrm{mL}$, and fungicidal effect against $C$. albicans with MIC and MBC values $0.4 \mu \mathrm{g} / \mathrm{mL}$. Finally, Weng et al. 
reported cadmium(II) supramolecular Kandinsky circles (96, Figure 16) with high antibacterial activity against Gram-positive methicillin-resistant S. aureus (MRSA) [196]. The MIC values of the different supramolecular were between 0.5 and $3 \mu \mathrm{g} / \mathrm{mL}$. The compounds $96 \mathbf{a}-\mathbf{9 6} \mathbf{c}$ were not active against $E$. coli and showed negligible toxicity to eukaryotic cells.

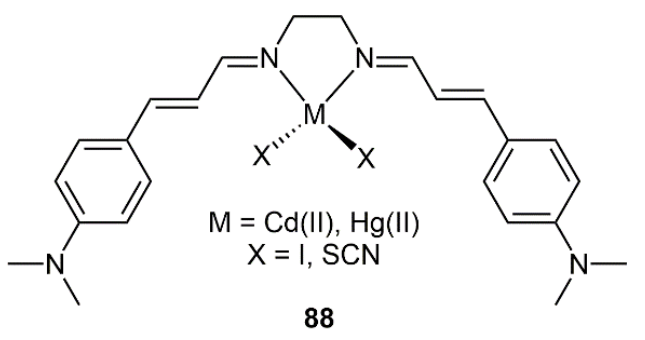

$\mathrm{MBC}=3.7-7.5 \mu \mathrm{g} / \mathrm{mL}$

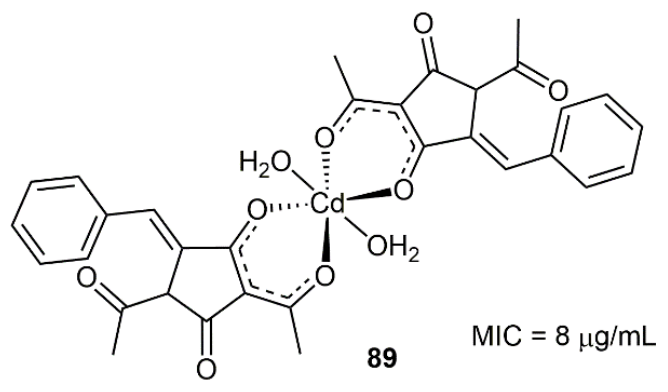

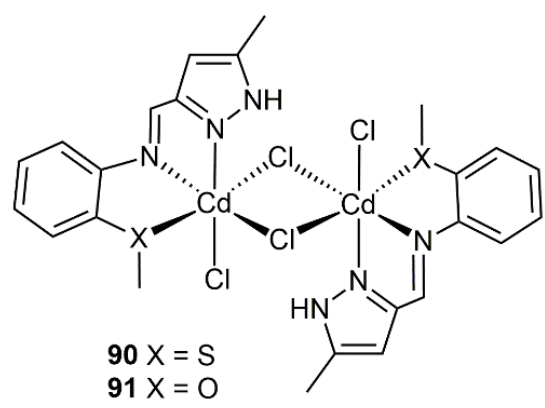

$\mathrm{MIC}=25-35 \mu \mathrm{g} / \mathrm{mL}$

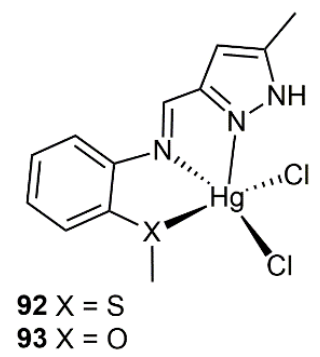

$\mathrm{MIC}=10 \mu \mathrm{g} / \mathrm{mL}$

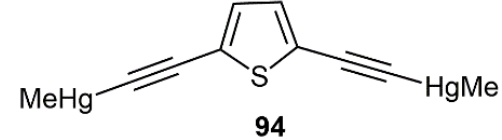

$\mathrm{MIC}=0.2-0.4 \mu \mathrm{g} / \mathrm{mL}$<smiles>CC#Cc1nc(-c2nc(C(C)(C)C)c(C(C)(C)C)s2)sc1C#CC</smiles>

$\mathrm{Cd}(\mathrm{II})=\mathrm{O}$

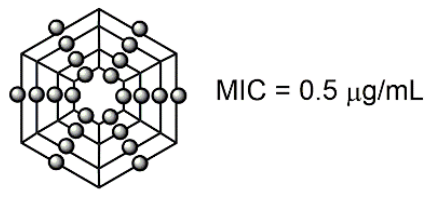

$96 \mathrm{c}$

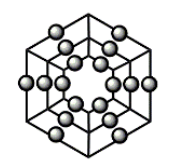

$\mathrm{MIC}=0.5 \mu \mathrm{g} / \mathrm{mL}$

$96 b$

$\mathrm{MIC}=3 \mu \mathrm{g} / \mathrm{mL}$

Figure 16. Structural formula of selected antimicrobial cadmium(II) and mercury(II) complexes.

\section{Conclusions}

In the last ten years, inorganic and organometallic transition metal medicinal chemists have begun to develop new antimicrobial agents with great promise and noteworthy success. Complexes of virtually all ions of the transition periods have been tested. In this review, we have detailed in particular recent studies on the antimicrobial activities and potential of transition metal complexes 
of groups 6-12. Several species show remarkable prospective as candidates for the development of new classes of highly active antimicrobial agents. The majority of compounds still need validation in vivo but the unique properties of the complexes offer the possibility of fine-tuning in the future their properties, reactivity and toxicological profiles. Metal complexes operate via specific modes of actions unknown to carbon-based drugs and yet unexperienced by infectious pathogens. This will likely translate into long-term new strategies in this urgent global fight.

Author Contributions: Both authors equally contributed to the work. All authors have read and agreed to the published version of the manuscript.

Funding: This research received no external funding.

Conflicts of Interest: The authors declare no conflict of interest.

\section{References}

1. Bush, K.; Courvalin, P.; Dantas, G.; Davies, J.; Eisenstein, B.; Huovinen, P.; Jacoby, G.A.; Kishony, R.; Kreiswirth, B.N.; Kutter, E.; et al. Tackling antibiotic resistance. Nat. Rev. Microbiol. 2011, 9, 894-896. [CrossRef]

2. Davies, J.; Davies, D. Origins and evolution of antibiotic resistance. Microbiol. Mol. Biol. Rev. 2010, 74, 417-433. [CrossRef]

3. Bouley, R.; Ding, D.; Peng, Z.; Bastian, M.; Lastochkin, E.; Song, W.; Suckow, M.A.; Schroeder, V.A.; Wolter, W.R.; Mobashery, S.; et al. Structure-Activity Relationship for the 4(3H)-Quinazolinone Antibacterials. J. Med. Chem. 2016, 59, 5011-5021. [CrossRef]

4. Ng, N.S.; Leverett, P.; Hibbs, D.E.; Yang, Q.; Bulanadi, J.C.; Wu, M.J.; Aldrich-Wright, J.R. The antimicrobial properties of some copper(II) and platinum(II) 1,10-phenanthroline complexes. Dalton Trans. 2013, 42, 3196-3209. [CrossRef]

5. Zhao, Y.; Chen, Z.; Chen, Y.; Xu, J.; Li, J.; Jiang, X. Synergy of non-antibiotic drugs and pyrimidinethiol on gold nanoparticles against superbugs. J. Am. Chem. Soc. 2013, 135, 12940-12943. [CrossRef]

6. Xia, J.; Gao, J.; Kokudo, N.; Hasegawa, K.; Tang, W. Methicillin-resistant Staphylococcus aureus antibiotic resistance and virulence. Biosci. Trends 2013, 7, 113-121.

7. Von Nussbaum, F.; Brands, M.; Hinzen, B.; Weigand, S.; Habich, D. Antibacterial natural products in medicinal chemistry-exodus or revival? Angew. Chem. Int. Ed. Engl. 2006, 45, 5072-5129. [CrossRef]

8. Pawlowski, A.C.; Johnson, J.W.; Wright, G.D. Evolving medicinal chemistry strategies in antibiotic discovery. Curr. Opin. Biotech. 2016, 42, 108-117. [CrossRef]

9. Talbot, G.H.; Jezek, A.; Murray, B.E.; Jones, R.N.; Ebright, R.H.; Nau, G.J.; Rodvold, K.A.; Newland, J.G.; Boucher, H.W.; Infectious Diseases Society of America. The Infectious Diseases Society of America's $10 \times$ '20 Initiative (10 New Systemic Antibacterial Agents US Food and Drug Administration Approved by 2020): Is $20 \times$ '20 a Possibility? Arch. Clin. Infect. Dis. 2019, 69, 1-11. [CrossRef]

10. Frei, A. Metal Complexes, an Untapped Source of Antibiotic Potential? Antibiotics 2020, 9, 90. [CrossRef]

11. Arias, L.S.; Pessan, J.P.; Vieira, A.P.M.; Lima, T.M.T.; Delbem, A.C.B.; Monteiro, D.R. Iron Oxide Nanoparticles for Biomedical Applications: A Perspective on Synthesis, Drugs, Antimicrobial Activity, and Toxicity. Antibiotics 2018, 7, 46. [CrossRef]

12. De Toledo, L.d.A.S.; Rosseto, H.C.; Bruschi, M.L. Iron oxide magnetic nanoparticles as antimicrobials for therapeutics. Pharm. Dev. Technol. 2018, 23, 316-323. [CrossRef]

13. Dutta, P.; Wang, B. Zeolite-supported silver as antimicrobial agents. Coord. Chem. Rev. 2019, 383, 1-29. [CrossRef]

14. Duval, R.E.; Gouyau, J.; Lamouroux, E. Limitations of Recent Studies Dealing with the Antibacterial Properties of Silver Nanoparticles: Fact and Opinion. Nanomaterials 2019, 9, 1775. [CrossRef]

15. Fahmy, H.M.; Mosleh, A.M.; Elghany, A.A.; Shams-Eldin, E.; Abu Serea, E.S.; Ali, S.A.; Shalan, A.E. Coated silver nanoparticles: Synthesis, cytotoxicity, and optical properties. RSC Adv. 2019, 9, 20118-20136. [CrossRef]

16. Gunawan, C.; Marquis, C.P.; Amal, R.; Sotiriou, G.A.; Rice, S.A.; Harry, E.J. Widespread and Indiscriminate Nanosilver Use: Genuine Potential for Microbial Resistance. ACS Nano 2017, 11, 3438-3445. [CrossRef]

17. Hashim, A.; Agool, I.R.; Kadhim, K.J. Modern Developments in Polymer Nanocomposites For Antibacterial and Antimicrobial Applications: A Review. J. Bionanosci. 2018, 12, 608-613. [CrossRef] 
18. Hussaini, S.Y.; Haque, R.A.; Razali, M.R. Recent progress in silver(I)-, gold(I)/(III)- and palladium(II)-Nheterocyclic carbene complexes: A review towards biological perspectives. J. Organomet. Chem. 2019, 882, 96-111. [CrossRef]

19. Leitao, J.H.; Sousa, S.A.; Leite, S.A.; Carvalho, M. Silver Camphor Imine Complexes: Novel Antibacterial Compounds from Old Medicines. Antibiotics 2018, 7, 65. [CrossRef]

20. Medici, S.; Peana, M.; Nurchi, V.M.; Zoroddu, M.A. Medical Uses of Silver: History, Myths, and Scientific Evidence. J. Med. Chem. 2019, 62, 5923-5943. [CrossRef]

21. Möhler, J.S.; Sim, W.; Blaskovich, M.A.T.; Cooper, M.A.; Ziora, Z.M. Silver bullets: A new lustre on an old antimicrobial agent. Biotech. Adv. 2018, 36, 1391-1411. [CrossRef] [PubMed]

22. Rusu, A.; Hancu, G.; Cristina Munteanu, A.; Uivarosi, V. Development perspectives of silver complexes with antibacterial quinolones: Successful or not? J. Organomet. Chem. 2017, 839, 19-30. [CrossRef]

23. Singh, R.; Shedbalkar, U.U.; Wadhwani, S.A.; Chopade, B.A. Bacteriagenic silver nanoparticles: Synthesis, mechanism, and applications. Appl. Microbiol. Biotechnol. 2015, 99, 4579-4593. [CrossRef] [PubMed]

24. Zheng, K.; Setyawati, M.I.; Leong, D.T.; Xie, J. Antimicrobial silver nanomaterials. Coord. Chem. Rev. 2018, 357, 1-17. [CrossRef]

25. Patil, S.A.; Patil, S.A.; Patil, R.; Keri, R.S.; Budagumpi, S.; Balakrishna, G.R.; Tacke, M. N-heterocyclic carbene metal complexes as bio-organometallic antimicrobial and anticancer drugs. Future Med. Chem. 2015, 7, 1305-1333. [CrossRef]

26. Li, F.; Collins, J.G.; Keene, F.R. Ruthenium complexes as antimicrobial agents. Chem. Soc. Rev. 2015, 44, 2529-2542. [CrossRef]

27. Patra, M.; Gasser, G.; Metzler-Nolte, N. Small organometallic compounds as antibacterial agents. Dalton Trans. 2012, 41, 6350-6358. [CrossRef]

28. Sierra, M.; Casarrubios, L.; De la Torre, M. Bio-Organometallic Derivatives of Antibacterial Drugs. Chemistry 2019, 25. [CrossRef]

29. Frei, A.; Zuegg, J.; Elliott, A.G.; Baker, M.; Braese, S.; Brown, C.; Chen, F.; C, G.D.; Dujardin, G.; Jung, N.; et al. Metal complexes as a promising source for new antibiotics. Chem. Sci. 2020, 11, 2627-2639. [CrossRef]

30. Kumar, S.P.; Suresh, R.; Giribabu, K.; Manigandan, R.; Munusamy, S.; Muthamizh, S.; Narayanan, V. Synthesis and characterization of chromium(III) Schiff base complexes: Antimicrobial activity and its electrocatalytic sensing ability of catechol. Spectrochim. Acta A 2015, 139, 431-441. [CrossRef]

31. Rathi, P.; Singh, D.P. Synthesis, antimicrobial, antioxidant and molecular docking studies of thiophene based macrocyclic Schiff base complexes. J. Mol. Struct. 2015, 1100, 208-214. [CrossRef]

32. Shaabani, B.; Khandar, A.A.; Ramazani, N.; Fleck, M.; Mobaiyen, H.; Cunha-Silva, L. Chromium(III), manganese(II) and iron(III) complexes based on hydrazone Schiff-base and azide ligands: Synthesis, crystal structure and antimicrobial activity. J. Coord. Chem. 2017, 70, 696-708. [CrossRef]

33. Kafi-Ahmadi, L.; Shirmohammadzadeh, L. Synthesis of $\mathrm{Co}(\mathrm{II})$ and $\mathrm{Cr}$ (III) salicylidenic Schiff base complexes derived from thiourea as precursors for nano-sized $\mathrm{Co}_{3} \mathrm{O}_{4}$ and $\mathrm{Cr}_{2} \mathrm{O}_{3}$ and their catalytic, antibacterial properties. J. Nanostruct. Chem. 2017, 7, 179-190. [CrossRef]

34. Abdel Rahman, L.H.; Abu-Dief, A.M.; Hamdan, S.K.; Seleem, A.A. Nano Structure Iron(II) and Copper(II) Schiff-Base Complexes of a NNO Tridentate Ligand as New Antibiotic Agents. Spectral Thermal Behaviors and Dann Binding Ability. Int. J. Nanomater. Chem. 2015, 1, 65-77. [CrossRef]

35. Abdel-Rahman, L.H.; El-Khatib, R.M.; Nassr, L.A.; Abu-Dief, A.M.; Ismael, M.; Seleem, A.A. Metal based pharmacologically active agents: Synthesis, structural characterization, molecular modeling, CT-DNA binding studies and in vitro antimicrobial screening of iron(II) bromosalicylidene amino acid chelates. Spectrochim. Acta Part A Mol. Biomol. Spectrosc. 2014, 117, 366-378. [CrossRef]

36. Abu-Dief, A.M.; Nassr, L.A.E. Tailoring, physicochemical characterization, antibacterial and DNA binding mode studies of $\mathrm{Cu}(\mathrm{II})$ Schiff bases amino acid bioactive agents incorporating 5-bromo-2hydroxybenzaldehyde. J. Iran. Chem. Soc. 2015, 12, 943-955. [CrossRef]

37. Liu, Y.-T.; Sheng, J.; Yin, D.-W.; Xin, H.; Yang, X.-M.; Qiao, Q.-Y.; Yang, Z.-J. Ferrocenyl chalcone-based Schiff bases and their metal complexes: Highly efficient, solvent-free synthesis, characterization, biological research. J. Organomet. Chem. 2018, 856, 27-33. [CrossRef]

38. Murcia, R.A.; Leal, S.M.; Roa, M.V.; Nagles, E.; Munoz-Castro, A.; Hurtado, J.J. Development of Antibacterial and Antifungal Triazole Chromium(III) and Cobalt(II) Complexes: Synthesis and Biological Activity Evaluations. Molecules 2018, 23, 2013. [CrossRef] 
39. Abu-Dief, A.M.; El-Sagher, H.M.; Shehata, M.R. Fabrication, spectroscopic characterization, calf thymus DNA binding investigation, antioxidant and anticancer activities of some antibiotic azomethine $\mathrm{Cu}(\mathrm{II}), \mathrm{Pd}(\mathrm{II})$, Zn(II) and Cr(III) complexes. Appl. Organomet. Chem. 2019, 33, e4943. [CrossRef]

40. El-Razek, S.E.A.; El-Gamasy, S.M.; Hassan, M.; Abdel-Aziz, M.S.; Nasr, S.M. Transition metal complexes of a multidentate Schiff base ligand containing guanidine moiety: Synthesis, characterization, anti-cancer effect, and anti-microbial activity. J. Mol. Struct. 2020, 1203, 127381. [CrossRef]

41. Abdel-Rahman, L.H.; Abu-Dief, A.M.; Newair, E.F.; Hamdan, S.K. Some new nano-sized Cr(III), Fe(II), Co(II), and $\mathrm{Ni}(\mathrm{II})$ complexes incorporating 2-((E)-(pyridine-2-ylimino)methyl)napthalen-1-ol ligand: Structural characterization, electrochemical, antioxidant, antimicrobial, antiviral assessment and DNA interaction. J. Photochem. Photobiol. 2016, 160, 18-31. [CrossRef] [PubMed]

42. Drzeżdżon, J.; Piotrowska-Kirschling, A.; Malinowski, J.; Kloska, A.; Gawdzik, B.; Chmurzyński, L.; Jacewicz, D. Antimicrobial, cytotoxic, and antioxidant activities and physicochemical characteristics of chromium(III) complexes with picolinate, dipicolinate, oxalate, 2,2'-bipyridine, and 4,4'-dimethoxy-2,2' bipyridine as ligands in aqueous solutions. J. Mol. Liq. 2019, 282, 441-447. [CrossRef]

43. Mahmoud, W.H.; Deghadi, R.G.; Mohamed, G.G. Metal complexes of novel Schiff base derived from iron sandwiched organometallic and 4-nitro-1,2-phenylenediamine: Synthesis, characterization, DFT studies, antimicrobial activities and molecular docking. Appl. Organomet. Chem. 2018, 32, e4289. [CrossRef]

44. Pahontu, E.; Usataia, I.; Graur, V.; Chumakov, Y.; Petrenko, P.; Gudumac, V.; Gulea, A. Synthesis, characterization, crystal structure of novel $\mathrm{Cu}(\mathrm{II}), \mathrm{Co}(\mathrm{III}), \mathrm{Fe}(\mathrm{III})$ and $\mathrm{Cr}$ (III) complexes with 2-hydroxybenzaldehyde-4-allyl$S$-methylisothiosemicarbazone: Antimicrobial, antioxidant and invitro antiproliferative activity. Appl. Organomet. Chem. 2018, 32, e4544. [CrossRef]

45. Srivastva, A.N.; Singh, N.P.; Shriwastaw, C.K. Physicochemical studies on bioactive Cr(III) coordination compounds with esters of hydrazine carboxylic acid as hetero donor ligands. Res. Chem. Intermed. 2017, 43, 5453-5465. [CrossRef]

46. Saraswat, K.; Kant, R. Synthesis characterization and biological activity of some molybdenum(VI) complexes. Der Pharma. Chem. 2013, 5, 347-356.

47. Wedd, A.G. Sulfido-Complexes of Molybdenum and Tungsten: Synthetic Aspects. In Studies in Inorganic Chemistry; Müller, A., Krebs, B., Eds.; Elsevier: Amsterdam, The Netherlands, 1984; Volume 5, pp. 181-193.

48. Zhang, L.; Nelson, K.J.; Rajagopalan, K.V.; George, G.N. Structure of the Molybdenum Site of Escherichia coli Trimethylamine N-Oxide Reductase. Inorg. Chem. 2008, 47, 1074-1078. [CrossRef]

49. Biswal, D.; Pramanik, N.R.; Chakrabarti, S.; Drew, M.G.B.; Mitra, P.; Acharya, K.; Biswas, S.; Mondal, T.K. Supramolecular frameworks of binuclear dioxomolybdenum(VI) complexes with ONS donor ligands using 4,4'-azopyridine as a pillar: Crystal structure, DFT calculations and biological study. N. J. Chem. 2015, 39, 8681-8694. [CrossRef]

50. Çelen, Ş.; Eğlence-Bakır, S.; Şahin, M.; Deniz, I.; Celik, H.; Kizilcikli, I. Synthesis and characterization of new thiosemicarbazonato molybdenum(VI) complexes and their in vitro antimicrobial activities. J. Coord. Chem. 2019, 72, 1747-1758. [CrossRef]

51. Sang, Y.-L.; Zhang, X.-H.; Lin, X.-S.; Liu, Y.-H.; Liu, X.-Y. Syntheses, crystal structures, and antibacterial activity of oxidovanadium(V) and dioxidomolybdenum(VI) complexes derived from $N^{\prime}$-(2-hydroxy4-methoxybenzylidene)isonicotinohydrazide. J. Coord. Chem. 2020, 73, 164-174. [CrossRef]

52. Kirakci, K.; Zelenka, J.; Rumlová, M.; Cvačka, J.; Ruml, T.; Lang, K. Cationic octahedral molybdenum cluster complexes functionalized with mitochondria-targeting ligands: Photodynamic anticancer and antibacterial activities. Biomater. Sci. 2019, 7, 1386-1392. [CrossRef]

53. Zampakou, M.; Akrivou, M.; Andreadou, E.G.; Raptopoulou, C.P.; Psycharis, V.; Pantazaki, A.A.; Psomas, G. Structure, antimicrobial activity, DNA- and albumin-binding of manganese(II) complexes with the quinolone antimicrobial agents oxolinic acid and enrofloxacin. J. Inorg. Biochem. 2013, 121, 88-99. [CrossRef]

54. Barmpa, A.; Frousiou, O.; Kalogiannis, S.; Perdih, F.; Turel, I.; Psomas, G. Manganese(II) complexes of the quinolone family member flumequine: Structure, antimicrobial activity and affinity for albumins and calf-thymus DNA. Polyhedron 2018, 145, 166-175. [CrossRef]

55. Arthi, P.; Shobana, S.; Srinivasan, P.; Prabhu, D.; Arulvasu, C.; Kalilur Rahiman, A. Dinuclear manganese(II) complexes of hexaazamacrocycles bearing $N$-benzoylated pendant separated by aromatic spacers: Antibacterial, DNA interaction, cytotoxic and molecular docking studies. J. Photoch. Photobio. B 2015, 153, 247-260. [CrossRef] 
56. Simpson, P.V.; Nagel, C.; Bruhn, H.; Schatzschneider, U. Antibacterial and Antiparasitic Activity of Manganese(I) Tricarbonyl Complexes with Ketoconazole, Miconazole, and Clotrimazole Ligands. Organometallics 2015, 34, 3809-3815. [CrossRef]

57. Dong, H.; Yang, X.; He, J.; Cai, S.; Xiao, K.; Zhu, L. Enhanced antioxidant activity, antibacterial activity and hypoglycemic effect of luteolin by complexation with manganese(II) and its inhibition kinetics on xanthine oxidase. RSC Adv. 2017, 7, 53385-53395. [CrossRef]

58. Güntzel, P.; Nagel, C.; Weigelt, J.; Betts, J.W.; Pattrick, C.A.; Southam, H.M.; La Ragione, R.M.; Poole, R.K.; Schatzschneider, U. Biological activity of manganese(I) tricarbonyl complexes on multidrug-resistant Gram-negative bacteria: From functional studies to in vivo activity in Galleria mellonella. Metallomics 2019, 11, 2033-2042. [CrossRef]

59. Kottelat, E.; Chabert, V.; Crochet, A.; Fromm, K.M.; Zobi, F. Towards Cardiolite-Inspired Carbon Monoxide Releasing Molecules-Reactivity of $\mathrm{d}^{4}, \mathrm{~d}^{5}$ Rhenium and $\mathrm{d}^{6}$ Manganese Carb-onyl Complexes with Isocyanide Ligands. Eur. J. Inorg. Chem. 2015, 2015, 5628-5638. [CrossRef]

60. Devi, P.P.; Chipem, F.A.S.; Singh, C.B.; Lonibala, R.K. Complexation of 2-amino-3-(4-hydroxyphenyl)$\mathrm{N}^{\prime}$-[(2-hydroxyphenyl) methylene] propane hydrazide with $\mathrm{Mn}(\mathrm{II}), \mathrm{Co}(\mathrm{II}), \mathrm{Ni}(\mathrm{II}), \mathrm{Cu}(\mathrm{II})$ and $\mathrm{Zn}(\mathrm{II})$ ions: Structural characterization, DFT, DNA binding and antimicrobial studies. J. Mol. Struct. 2019, 1176, 7-18. [CrossRef]

61. Jayakumar, S.; Mahendiran, D.; Rahiman, A.K. Theoretical, antimicrobial, antioxidant, in vitro cytotoxicity, and cyclin-dependent kinase 2 inhibitor studies of metal(II) complexes with bis(imidazol-1-yl)methane-based heteroscorpionate ligands. J. Coord. Chem. 2019, 72, 2015-2034. [CrossRef]

62. Özgür, M.; Yılmaz, M.; Nishino, H.; Çinar Avar, E.; Dal, H.; Pekel, A.T.; Hökelek, T. Efficient syntheses and antimicrobial activities of new thiophene containing pyranone and quinolinone derivatives using manganese(III) acetate: The effect of thiophene on ring closure-opening reactions. N. J. Chem. 2019, 43, 5737-5751. [CrossRef]

63. Pulina, N.A.; Kuznetsov, A.S.; Krasnova, A.I.; Novikova, V.V. Synthesis, Antimicrobial Activity, and Behavioral Response Effects of N-Substituted 4-Aryl-2-Hydroxy-4-Oxobut-2-Enoic Acid Hydrazides and Their Metal Complexes. Pharm. Chem. J. 2019, 53, 220-224. [CrossRef]

64. Betts, J.; Nagel, C.; Schatzschneider, U.; Poole, R.; La Ragione, R.M. Antimicrobial activity of carbon monoxide-releasing molecule $\left[\mathrm{Mn}(\mathrm{CO})_{3}\left(\mathrm{tpa}-\mathrm{k}^{3} \mathrm{~N}\right)\right] \mathrm{Br}$ versus multidrug-resistant isolates of Avian Pathogenic Escherichia coli and its synergy with colistin. PLoS ONE 2017, 12, e0186359. [CrossRef]

65. Nagel, C.; McLean, S.; Poole, R.K.; Braunschweig, H.; Kramer, T.; Schatzschneider, U. Introducing $\left[\mathrm{Mn}(\mathrm{CO})_{3}\left(\mathrm{tpa}^{3} \mathrm{k}^{3} \mathrm{~N}\right)\right]^{+}$as a novel photoactivatable CO-releasing molecule with well-defined iCORM intermediates-synthesis, spectroscopy, and antibacterial activity. Dalton Trans. 2014, 43, 9986-9997. [CrossRef]

66. Rana, N.; Jesse, H.E.; Tinajero-Trejo, M.; Butler, J.A.; Tarlit, J.D.; von Und Zur Muhlen, M.L.; Nagel, C.; Schatzschneider, U.; Poole, R.K. A manganese photosensitive tricarbonyl molecule $\left[\mathrm{Mn}(\mathrm{CO})_{3}\left(\mathrm{tpa}-\mathrm{k}^{3} \mathrm{~N}\right)\right] \mathrm{Br}$ enhances antibiotic efficacy in a multi-drug-resistant Escherichia coli. Microbiology 2017, 163, 1477-1489. [CrossRef]

67. Tinajero-Trejo, M.; Rana, N.; Nagel, C.; Jesse, H.E.; Smith, T.W.; Wareham, L.K.; Poole, R.K. Antimicrobial Activity of the Manganese Photoactivated Carbon Monoxide-Releasing Molecule $\left[\mathrm{Mn}(\mathrm{CO})_{3}\left(\mathrm{tpa}-\mathrm{k}^{3} \mathrm{~N}\right)\right]^{+}$ Against a Pathogenic Escherichia coli that Causes Urinary Infections. Antioxid. Redox. Sign. 2016, 24, 765-780. [CrossRef]

68. Ward, J.S.; Lynam, J.M.; Moir, J.; Fairlamb, I.J.S. Visible-Light-Induced CO Release from a Therapeutically Viable Tryptophan-Derived Manganese(I) Carbonyl (TryptoCORM) Exhibiting Potent Inhibition against E. coli. Chem. Eur. J. 2014, 20, 15061-15068. [CrossRef]

69. Ward, J.S.; Morgan, R.; Lynam, J.M.; Fairlamb, I.J.S.; Moir, J.W.B. Toxicity of tryptophan manganese(I) carbonyl (Trypto-CORM), against Neisseria gonorrhoeae. Med. Chem. Commun. 2017, 8, 346-352. [CrossRef]

70. Crook, S.H.; Mann, B.E.; Meijer, A.J.H.M.; Adams, H.; Sawle, P.; Scapens, D.; Motterlini, R. $\left[\mathrm{Mn}(\mathrm{CO})_{4}\left(\mathrm{~S}_{2} \mathrm{CNMe}\left(\mathrm{CH}_{2} \mathrm{CO}_{2} \mathrm{H}\right)\right)\right]$, a new water-soluble CO-releasing molecule. Dalton Trans. 2011, 40, 4230-4235. [CrossRef]

71. Wareham, L.K.; McLean, S.; Begg, R.; Rana, N.; Ali, S.; Kendall, J.J.; Sanguinetti, G.; Mann, B.E.; Poole, R.K. The Broad-Spectrum Antimicrobial Potential of $\left[\mathrm{Mn}(\mathrm{CO})_{4}\left(\mathrm{~S}_{2} \mathrm{CNMe}\left(\mathrm{CH}_{2} \mathrm{CO}_{2} \mathrm{H}\right)\right)\right]$, a Water-Soluble CO-Releasing Molecule (CORM-401): Intracellular Accumulation, Transcriptomic and Statistical Analyses, and Membrane Polarization. Antioxid. Redox Signal. 2018, 28, 1286-1308. [CrossRef] 
72. Noor, A.; Huff, G.S.; Kumar, S.V.; Lewis, J.E.M.; Paterson, B.M.; Schieber, C.; Donnelly, P.S.; Brooks, H.J.L.; Gordon, K.C.; Moratti, S.C.; et al. $\left[\operatorname{Re}(\mathrm{CO})_{3}\right]^{+}$Complexes of exo-Functionalized Tridentate "Click" Macrocycles: Synthesis, Stability, Photophysical Properties, Bioconjugation, and Antibacterial Activity. Organometallics 2014, 33, 7031-7043. [CrossRef]

73. Patra, M.; Wenzel, M.; Prochnow, P.; Pierroz, V.; Gasser, G.; Bandow, J.E.; Metzler-Nolte, N. An organometallic structure-activity relationship study reveals the essential role of a $\operatorname{Re}(\mathrm{CO})_{3}$ moiety in the activity against gram-positive pathogens including MRSA. Chem. Sci. 2015, 6, 214-224. [CrossRef]

74. Kumar, S.V.; Lo, W.K.C.; Brooks, H.J.L.; Hanton, L.R.; Crowley, J.D. Antimicrobial Properties of Mono- and Di-fac-rhenium Tricarbonyl 2-Pyridyl-1,2,3-triazole Complexes. Aust. J. Chem. 2016, 69, 489-498. [CrossRef]

75. Siegmund, D.; Lorenz, N.; Gothe, Y.; Spies, C.; Geissler, B.; Prochnow, P.; Nuernberger, P.; Bandow, J.E.; Metzler-Nolte, N. Benzannulated Re(I)-NHC complexes: Synthesis, photophysical properties and antimicrobial activity. Dalton Trans. 2017, 46, 15269-15279. [CrossRef]

76. Frei, A.; Amado, M.; Cooper, M.A.; Blaskovich, M.A.T. Light-Activated Rhenium Complexes with Dual Mode of Action against Bacteria. Chem. Eur. J. 2020, 26, 2852-2858. [CrossRef]

77. Carreño, A.; Solís-Céspedes, E.; Zúñiga, C.; Nevermann, J.; Rivera-Zaldívar, M.M.; Gacitúa, M.; Ramírez-Osorio, A.; Páez-Hernández, D.; Arratia-Pérez, R.; Fuentes, J.A. Cyclic voltammetry, relativistic DFT calculations and biological test of cytotoxicity in walled-cell models of two classical rhenium(I) tricarbonyl complexes with 5-amine-1,10-phenanthroline. Chem. Phys. Lett. 2019, 715, 231-238. [CrossRef]

78. Kydonaki, T.E.; Tsoukas, E.; Mendes, F.; Hatzidimitriou, A.G.; Paulo, A.; Papadopoulou, L.C.; Papagiannopoulou, D.; Psomas, G. Synthesis, characterization and biological evaluation of 99mTc/Re-tricarbonyl quinolone complexes. J. Inorg. Biochem. 2016, 160, 94-105. [CrossRef]

79. Miller, R.G.; Vázquez-Hernández, M.; Prochnow, P.; Bandow, J.E.; Metzler-Nolte, N. A CuAAC Click Approach for the Introduction of Bidentate Metal Complexes to a Sulfanilamide-Derived Antibiotic Fragment. Inorg. Chem. 2019, 58, 9404-9413. [CrossRef]

80. Pagoni, C.-C.; Xylouri, V.-S.; Kaiafas, G.C.; Lazou, M.; Bompola, G.; Tsoukas, E.; Papadopoulou, L.C.; Psomas, G.; Papagiannopoulou, D. Organometallic rhenium tricarbonyl-enrofloxacin and -levofloxacin complexes: Synthesis, albumin-binding, DNA-interaction and cell viability studies. J. Biol. Inorg. Chem. 2019, 24, 609-619. [CrossRef]

81. Howson, S.E.; Bolhuis, A.; Brabec, V.; Clarkson, G.J.; Malina, J.; Rodger, A.; Scott, P. Optically pure, water-stable metallo-helical 'flexicate' assemblies with antibiotic activity. Nat. Chem. 2012, 4, 31-36. [CrossRef]

82. Allardyce, C.S.; Dyson, P.J. Ruthenium in Medicine_C Current Clinical Uses and Future Prospects. Platin. Met. Rev. 2001, 45, 62-69.

83. Atton, J.G.D.M.; Gillard, R.D. Equilibria in complexes of N-heterocyclic ligands. Part 33. Ruthenium(II) complex ions with chelating pyridyl-imidazoles. Transit. Met. Chem. 1981, 6, 351-355. [CrossRef]

84. Bolhuis, A.; Hand, L.; Marshall, J.E.; Richards, A.D.; Rodger, A.; Aldrich-Wright, J. Antimicrobial activity of ruthenium-based intercalators. Eur. J. Pharm. Sci. 2011, 42, 313-317. [CrossRef]

85. Gill, M.R.; Garcia-Lara, J.; Foster, S.J.; Smythe, C.; Battaglia, G.; Thomas, J.A. A ruthenium(II) polypyridyl complex for direct imaging of DNA structure in living cells. Nat. Chem. 2009, 1, 662-667. [CrossRef]

86. Gill, M.R.; Thomas, J.A. Ruthenium(II) polypyridyl complexes and DNA—from structural probes to cellular imaging and therapeutics. Chem. Soc. Rev. 2012, 41, 3179-3192. [CrossRef]

87. Keene, F.R.; Smith, J.A.; Collins, J.G. Metal complexes as structure-selective binding agents for nucleic acids. Coord. Chem. Rev. 2009, 253, 2021-2035. [CrossRef]

88. Luedtke, N.W.; Hwang, J.S.; Nava, E.; Gut, D.; Kol, M.; Tor, Y. The DNA and RNA specificity of eilatin Ru(II) complexes as compared to eilatin and ethidium bromide. Nucleic Acids Res. 2003, 31, 5732-5740. [CrossRef]

89. Matson, M.; Svensson, F.R.; Nordén, B.; Lincoln, P. Correlation Between Cellular Localization and Binding Preference to RNA, DNA, and Phospholipid Membrane for Luminescent Ruthenium(II) Complexes. J. Phys. Chem. B 2011, 115, 1706-1711. [CrossRef]

90. Metcalfe, C.; Thomas, J.A. Kinetically inert transition metal complexes that reversibly bind to DNA. Chem. Soc. Rev. 2003, 32, 215-224. [CrossRef]

91. Norden, B.; Lincoln, P.; Akerman, B.; Tuite, E. DNA interactions with substitution-inert transition metal ion complexes. Met. Ions Biol. Syst. 1996, 33, 177-252. 
92. Puckett, C.A.; Barton, J.K. Mechanism of Cellular Uptake of a Ruthenium Polypyridyl Complex. Biochemistry 2008, 47, 11711-11716. [CrossRef]

93. Zeglis, B.M.; Pierre, V.C.; Barton, J.K. Metallo-intercalators and metallo-insertors. Chem. Commun. 2007, 44, 4565-4579. [CrossRef]

94. Kumar, S.V.; Scottwell, S.Ø.; Waugh, E.; McAdam, C.J.; Hanton, L.R.; Brooks, H.J.L.; Crowley, J.D. Antimicrobial Properties of Tris(homoleptic) Ruthenium(II) 2-Pyridyl-1,2,3-triazole "Click" Complexes against Pathogenic Bacteria, Including Methicillin-Resistant Staphylococcus aureus (MRSA). Inorg. Chem. 2016, 55, 9767-9777. [CrossRef]

95. Liao, G.; Ye, Z.; Liu, Y.; Fu, B.; Fu, C. Octahedral ruthenium(II) polypyridyl complexes as antimicrobial agents against mycobacterium. PeerJ. 2017, 5, e3252. [CrossRef]

96. Li, X.; Heimann, K.; Li, F.; Warner, J.M.; Richard Keene, F.; Grant Collins, J. Dinuclear ruthenium(II) complexes containing one inert metal centre and one coordinatively-labile metal centre: Syntheses and biological activities. Dalton Trans. 2016, 45, 4017-4029. [CrossRef]

97. Srivastava, P.; Shukla, M.; Kaul, G.; Chopra, S.; Patra, A.K. Rationally designed curcumin based ruthenium(II) antimicrobials effective against drug-resistant Staphylococcus aureus. Dalton Trans. 2019, 48, 11822-11828. [CrossRef]

98. Kreofsky, N.W.; Dillenburg, M.D.; Villa, E.M.; Fletcher, J.T. Ru(II) coordination compounds of NN bidentate chelators with 1,2,3 triazole and isoquinoline subunits: Synthesis, spectroscopy and antimicrobial properties. Polyhedron 2020, 177, 114259. [CrossRef]

99. Van Hilst, Q.V.C.; Vasdev, R.A.S.; Preston, D.; Findlay, J.A.; Scottwell, S.Ø.; Giles, G.I.; Brooks, H.J.L.; Crowley, J.D. Synthesis, Characterisation and Antimicrobial Studies of some 2,6-bis(1,2,3-Triazol-4-yl)Pyridine Ruthenium(II) "Click" Complexes. Asian J. Org. Chem. 2019, 8, 496-505. [CrossRef]

100. Sun, B.; Sundaraneedi, M.K.; Southam, H.M.; Poole, R.K.; Musgrave, I.F.; Keene, F.R.; Collins, J.G. Synthesis and biological properties of tetranuclear ruthenium complexes containing the bis[4(4'-methyl2,2'-bipyridyl)]-1,7-heptane ligand. Dalton Trans. 2019, 48, 14505-14515. [CrossRef]

101. Menéndez-Pedregal, E.; Manteca, Á.; Sánchez, J.; Díez, J.; Gamasa, M.P.; Lastra, E. Antimicrobial and Antitumor Activity of Enantiopure Pybox-Osmium Complexes. Eur. J. Inorg. Chem. 2015, 2015, 1424-1432. [CrossRef]

102. Gichumbi, J.M.; Friedrich, H.B.; Omondi, B.; Naicker, K.; Singh, M.; Chenia, H.Y. Synthesis, characterization, antiproliferative, and antimicrobial activity of osmium(II) half-sandwich complexes. J. Coord. Chem. 2018, 71, 342-354. [CrossRef]

103. Zhu, Y.; Li, W.-H. Syntheses, crystal structures and antibacterial activities of azido-bridged cobalt(III) complexes with Schiff bases. Transition Met. Chem. 2010, 35, 745-749. [CrossRef]

104. Anjaneyulu, Y.; Rao, R.P. Preparation, Characterization and Antimicrobial Activity Studies on Some Ternary Complexes of $\mathrm{Cu}(\mathrm{II})$ with Acetylacetone and Various Salicylic Acids. Synth. React. Inorg. Met. Org. Chem. 1986, 16, 257-272. [CrossRef]

105. Dharmaraj, N.; Viswanathamurthi, P.; Natarajan, K. Ruthenium(II) complexes containing bidentate Schiff bases and their antifungal activity. Transit. Met. Chem. 2001, 26, 105-109. [CrossRef]

106. Irgi, E.P.; Geromichalos, G.D.; Balala, S.; Kljun, J.; Kalogiannis, S.; Papadopoulos, A.; Turel, I.; Psomas, G. Cobalt(II) complexes with the quinolone antimicrobial drug oxolinic acid: Structure and biological perspectives. RSC Adv. 2015, 5, 36353-36367. [CrossRef]

107. Kouris, E.; Kalogiannis, S.; Perdih, F.; Turel, I.; Psomas, G. Cobalt(II) complexes of sparfloxacin: Characterization, structure, antimicrobial activity and interaction with DNA and albumins. J. Inorg. Biochem. 2016, 163, 18-27. [CrossRef]

108. Turecka, K.; Chylewska, A.; Kawiak, A.; Waleron, K.F. Antifungal Activity and Mechanism of Action of the Co(III) Coordination Complexes With Diamine Chelate Ligands Against Reference and Clinical Strains of Candida spp. Front. Microbiol. 2018, 9. [CrossRef]

109. Unluer, D.; Aktas Kamiloglu, A.; Direkel, S.; Bektas, E.; Kantekin, H.; Sancak, K. Synthesis and characterization of metallophthalocyanine with morpholine containing Schiff base and determination of their antimicrobial and antioxidant activities. J. Organomet. Chem. 2019, 900, 120936. [CrossRef] 
110. Balan, G.; Burduniuc, O.; Usataia, I.; Graur, V.; Chumakov, Y.; Petrenko, P.; Gudumac, V.; Gulea, A.; Pahontu, E. Novel 2-formylpyridine 4-allyl-S-methylisothiosemicarbazone and Zn(II), Cu(II), Ni(II) and Co(III) complexes: Synthesis, characterization, crystal structure, antioxidant, antimicrobial and antiproliferative activity. Appl. Organomet. Chem. 2020, 34, e5423. [CrossRef]

111. Casanova, I.; Durán, M.L.; Viqueira, J.; Sousa-Pedrares, A.; Zani, F.; Real, J.A.; García-Vázquez, J.A. Metal complexes of a novel heterocyclic benzimidazole ligand formed by rearrangement-cyclization of the corresponding Schiff base. Electrosynthesis, structural characterization and antimicrobial activity. Dalton Trans. 2018, 47, 4325-4340. [CrossRef]

112. Chandrasekhar, V.R.; Mookkandi Palsamy, K.; Lokesh, R.; Jegathalaprathaban, R.; Gurusamy, R. Biomolecular docking, antimicrobial and cytotoxic studies on new bidentate schiff base ligand derived metal(II) complexes. Appl. Organomet. Chem. 2019, 33, e4753. [CrossRef]

113. Ebrahimipour, S.Y.; Machura, B.; Mohamadi, M.; Khaleghi, M. A novel cationic cobalt(III) Schiff base complex: Preparation, crystal structure, Hirshfeld surface analysis, antimicrobial activities and molecular docking. Microb. Pathog. 2017, 113, 160-167. [CrossRef] [PubMed]

114. Gałczyńska, K.; Ciepluch, K.; Madej, Ł.; Kurdziel, K.; Maciejewska, B.; Drulis-Kawa, Z.; Węgierek-Ciuk, A.; Lankoff, A.; Arabski, M. Selective cytotoxicity and antifungal properties of copper(II) and cobalt(II) complexes with imidazole-4-acetate anion or 1-allylimidazole. Sci. Rep. 2019, 9, 9777. [CrossRef] [PubMed]

115. Orojloo, M.; Zolgharnein, P.; Solimannejad, M.; Amani, S. Synthesis and characterization of cobalt(II), nickel(II), copper(II) and zinc(II) complexes derived from two Schiff base ligands: Spectroscopic, thermal, magnetic moment, electrochemical and antimicrobial studies. Inorg. Chim. Acta 2017, 467, 227-237. [CrossRef]

116. Palmucci, J.; Mahmudov, K.T.; Guedes da Silva, M.F.C.; Marchetti, F.; Pettinari, C.; Petrelli, D.; Vitali, L.A.; Quassinti, L.; Bramucci, M.; Lupidi, G.; et al. DNA and BSA binding, anticancer and antimicrobial properties of $\mathrm{Co}(\mathrm{II}), \mathrm{Co}(\mathrm{II} / \mathrm{III}), \mathrm{Cu}(\mathrm{II})$ and $\mathrm{Ag}(\mathrm{I})$ complexes of arylhydrazones of barbituric acid. RSC Adv. 2016, 6, 4237-4249. [CrossRef]

117. Sadhu, M.H.; Kumar, S.B.; Saini, J.K.; Purani, S.S.; Khanna, T.R. Mononuclear copper(II) and binuclear cobalt(II) complexes with halides and tetradentate nitrogen coordinate ligand: Synthesis, structures and bioactivities. Inorg. Chim. Acta 2017, 466, 219-227. [CrossRef]

118. Saha, M.; Biswas, J.K.; Mondal, M.; Ghosh, D.; Mandal, S.; Cordes, D.B.; Slawin, A.M.Z.; Mandal, T.K.; Saha, N.C. Synthesis, characterization and antimicrobial activities of $\mathrm{Co}(\mathrm{III})$ and $\mathrm{Ni}(\mathrm{II})$ complexes with 5-methyl-3-formylpyrazole-N(4)-dihexylthiosemicarbazone ( $\left.\mathrm{HMPzNHex}_{2}\right)$ : X-ray crystallography and DFT calculations of $\left[\mathrm{Co}\left(\mathrm{MPzNHex}_{2}\right)_{2}\right] \mathrm{ClO}_{4} \cdot 1.5 \mathrm{H}_{2} \mathrm{O}$ (I) and [ $\left.\mathrm{Ni}\left(\mathrm{HMPzNHex}_{2}\right)_{2}\right] \mathrm{Cl}_{2} \cdot 2 \mathrm{H}_{2} \mathrm{O}$ (II). Inorg. Chim. Acta 2018, 483, 271-283. [CrossRef]

119. Saha, S.; Sasmal, A.; Roy Choudhury, C.; Pilet, G.; Bauzá, A.; Frontera, A.; Chakraborty, S.; Mitra, S. Synthesis, crystal structure, antimicrobial screening and density functional theory calculation of nickel(II), cobalt(II) and zinc(II) mononuclear Schiff base complexes. Inorg. Chim. Acta 2015, 425, 211-220. [CrossRef]

120. Vasdev, R.A.; Preston, D.; Scottwell, S.O.; Brooks, H.J.; Crowley, J.D.; Schramm, M.P. Oxidatively Locked $[\mathrm{Co}(2) \mathrm{L}(3)]^{6+}$ Cylinders Derived from Bis(bidentate) 2-Pyridyl-1,2,3-triazole “Click" Ligands: Synthesis, Stability, and Antimicrobial Studies. Molecules 2016, 21, 1548. [CrossRef]

121. Woźniczka, M.; Świątek, M.; Pająk, M.; Gądek-Sobczyńska, J.; Chmiela, M.; Gonciarz, W.; Lisiecki, P.; Pasternak, B.; Kufelnicki, A. Complexes in aqueous cobalt(II)-2-picolinehydroxamic acid system: Formation equilibria, DNA-binding ability, antimicrobial and cytotoxic properties. J. Inorg. Biochem. 2018, 187, 62-72. [CrossRef]

122. Lu, L.; Liu, L.J.; Chao, W.C.; Zhong, H.J.; Wang, M.; Chen, X.P.; Lu, J.J.; Li, R.N.; Ma, D.L.; Leung, C.H. Identification of an iridium(III) complex with anti-bacterial and anti-cancer activity. Sci. Rep. 2015, 5, e14544. [CrossRef]

123. Fiorini, V.; Zanoni, I.; Zacchini, S.; Costa, A.L.; Hochkoeppler, A.; Zanotti, V.; Ranieri, A.M.; Massi, M.; Stefan, A.; Stagni, S. Methylation of Ir(III)-tetrazolato complexes: An effective route to modulate the emission outputs and to switch to antimicrobial properties. Dalton Trans. 2017, 46, 12328-12338. [CrossRef]

124. Kumar, S.; Purcell, W.; Conradie, J.; Bragg, R.R.; Langner, E.H.G. Synthesis, characterization, computational and antimicrobial activities of a novel iridium thiourea complex. New J. Chem. 2017, 41, 10919-10928. [CrossRef]

125. DuChane, C.M.; Brown, L.C.; Dozier, V.S.; Merola, J.S. Synthesis, Characterization, and Antimicrobial Activity of Rh(III) and Ir(III) $\beta$-Diketonato Piano-Stool Compounds. Organometallics 2018, 37, 530-538. [CrossRef] 
126. Lapasam, A.; Dkhar, L.; Joshi, N.; Poluri, K.M.; Kollipara, M.R. Antimicrobial selectivity of ruthenium, rhodium, and iridium half sandwich complexes containing phenyl hydrazone Schiff base ligands towards B. thuringiensis and P. aeruginosa bacteria. Inorg. Chim. Acta 2019, 484, 255-263. [CrossRef]

127. Lapasam, A.; Banothu, V.; Uma, A.; Kollipara, M. Synthesis, structural and antimicrobial studies of half-sandwich ruthenium, rhodium and iridium complexes containing nitrogen donor Schiff-base ligands. J. Mol. Struct. 2019, 1191. [CrossRef]

128. Liu, B.; Monro, S.; Jabed, M.A.; Cameron, C.G.; Colón, K.L.; Xu, W.; Kilina, S.; McFarland, S.A.; Sun, W. Neutral iridium(III) complexes bearing BODIPY-substituted $N$-heterocyclic carbene (NHC) ligands: Synthesis, photophysics, in vitro theranostic photodynamic therapy, and antimicrobial activity. Photochem. Photobiol. Sci. 2019, 18, 2381-2396. [CrossRef] [PubMed]

129. Chen, F.; Moat, J.; McFeely, D.; Clarkson, G.; Hands-Portman, I.J.; Furner-Pardoe, J.P.; Harrison, F.; Dowson, C.G.; Sadler, P.J. Biguanide Iridium(III) Complexes with Potent Antimicrobial Activity. J. Med. Chem. 2018, 61, 7330-7344. [CrossRef] [PubMed]

130. DuChane, C.M.; Karpin, G.W.; Ehrich, M.; Falkinham, J.O.; Merola, J.S. Iridium piano stool complexes with activity against $\mathrm{S}$. aureus and MRSA: It is past time to truly think outside of the box. Med. Chem. Commun. 2019, 10, 1391-1398. [CrossRef]

131. Lapasam, A.; Banothu, V.; Addepally, U.; Kollipara, M.R. Half-sandwich arene ruthenium, rhodium and iridium thiosemicarbazone complexes: Synthesis, characterization and biological evaluation. J. Chem. Sci. 2020, 132, 34. [CrossRef]

132. Raj, P.; Singh, A.; Singh, A.; Singh, N. Syntheses and Photophysical Properties of Schiff Base Ni(II) Complexes: Application for Sustainable Antibacterial Activity and Cytotoxicity. ACS Sustain. Chem. Eng. 2017, 5, 6070-6080. [CrossRef]

133. Ibrahim, A.B.M.; Farh, M.K.; El-Gyar, S.A.; El-Gahami, M.A.; Fouad, D.M.; Silva, F.; Santos, I.C.; Paulo, A. Synthesis, structural studies and antimicrobial activities of manganese, nickel and copper complexes of two new tridentate 2-formylpyridine thiosemicarbazone ligands. Inorg. Chem. Commun. 2018, 96, 194-201. [CrossRef]

134. Juribašić, M.; Molčanov, K.; Kojić-Prodić, B.; Bellotto, L.; Kralj, M.; Zani, F.; Tušek-Božić, L. Palladium(II) complexes of quinolinylaminophosphonates: Synthesis, structural characterization, antitumor and antimicrobial activity. J. Inorg. Biochem. 2011, 105, 867-879. [CrossRef] [PubMed]

135. Tamayo, L.V.; Burgos, A.E.; Brandão, P.F.B. Synthesis, Characterization, and Antimicrobial Activity of the Ligand 3-Methylpyrazole- 4-Carboxaldehyde Thiosemicarbazone and Its Pd(II) Complex. Phosphorus Sulfur Relat. Elem. 2014, 189, 52-59. [CrossRef]

136. Radić, G.P.; Glođović, V.V.; Radojević, I.D.; Stefanović, O.D.; Čomić, L.R.; Ratković, Z.R.; Valkonen, A.; Rissanen, K.; Trifunović, S.R. Synthesis, characterization and antimicrobial activity of palladium(II) complexes with some alkyl derivates of thiosalicylic acids: Crystal structure of the bis(S-benzylthiosalicylate)-palladium(II) complex, [Pd(S-bz-thiosal) 2 ]. Polyhedron 2012, 31, 69-76. [CrossRef]

137. Boubakri, L.; Mansour, L.; Harrath, A.H.; Özdemir, I.; Yaşar, S.; Hamdi, N. N-Heterocyclic carbene-Pd(II)-PPh 3 complexes as a new highly efficient catalyst system for the Sonogashira cross-coupling reaction: Synthesis, characterization and biological activities. J. Coord. Chem. 2018, 71, 183-199. [CrossRef]

138. Abu-Dief, A.M.; Abdel-Rahman, L.H.; Abdel-Mawgoud, A.A.H. A robust in vitro Anticancer, Antioxidant and Antimicrobial Agents Based on New Metal-Azomethine Chelates Incorporating Ag(I), Pd(II) and VO(II) Cations: Probing the Aspects of DNA Interaction. Appl. Organomet. Chem. 2020, 34, e5373. [CrossRef]

139. Nyawade, E.A.; Onani, M.O.; Meyer, S.; Dube, P. Synthesis, characterization and antibacterial activity studies of new 2-pyrral-L-amino acid Schiff base palladium (II) complexes. Chem. Pap. 2020, 1-11. [CrossRef]

140. Solmaz, U.; Gumus, I.; Binzet, G.; Celik, O.; Balci, G.K.; Dogen, A.; Arslan, H. Synthesis, characterization, crystal structure, and antimicrobial studies of novel thiourea derivative ligands and their platinum complexes. J. Coord. Chem. 2018, 71, 200-218. [CrossRef]

141. Gaber, M.; El-Ghamry, H.A.; Mansour, M.A. Pd(II) and Pt(II) chalcone complexes. Synthesis, spectral characterization, molecular modeling, biomolecular docking, antimicrobial and antitumor activities. J. Photochem. Photobiol. 2018, 354, 163-174. [CrossRef]

142. Mansour, A.M. Antifungal activity, DNA and lysozyme binding affinity of $\mathrm{Pd}(\mathrm{II})$ and $\mathrm{Pt}(\mathrm{II})$ complexes bearing N,N-pyridylbenzimidazole ligand. J. Coord. Chem. 2018, 71, 3381-3391. [CrossRef] 
143. Lunagariya, M.V.; Thakor, K.P.; Varma, R.R.; Waghela, B.N.; Pathak, C.; Patel, M.N. Synthesis, characterization and biological application of 5-quinoline 1,3,5-trisubstituted pyrazole based platinum(II) complexes. Med. Chem. Commun. 2018, 9, 282-298. [CrossRef]

144. Gao, S.; Yan, X.; Xie, G.; Zhu, M.; Ju, X.; Stang, P.J.; Tian, Y.; Niu, Z. Membrane intercalation-enhanced photodynamic inactivation of bacteria by a metallacycle and TAT-decorated virus coat protein. Proc. Natl. Acad. Sci. USA 2019, 116, 23437-23443. [CrossRef]

145. Alam, M.N.; Yu, J.Q.; Beale, P.; Turner, P.; Proschogo, N.; Huq, F. Crystal Structure, Antitumour and Antibacterial Activity of Imidazo[1, 2- $\alpha$ ]pyridine Ligand Containing Palladium Complexes. ChemistrySelect 2020, 5, 668-673. [CrossRef]

146. Basto, A.P.; Muller, J.; Rubbiani, R.; Stibal, D.; Giannini, F.; Suss-Fink, G.; Balmer, V.; Hemphill, A.; Gasser, G.; Furrer, J. Characterization of the Activities of Dinuclear Thiolato-Bridged Arene Ruthenium Complexes against Toxoplasma gondii. Antimicrob. Agents Chemother. 2017, 61, e01031-17. [CrossRef] [PubMed]

147. Bugarčić, Z.M.; Divac, V.M.; Kostić, M.D.; Janković, N.Ž.; Heinemann, F.W.; Radulović, N.S.; Stojanović-Radić, Z.Z. Synthesis, crystal and solution structures and antimicrobial screening of palladium(II) complexes with 2-(phenylselanylmethyl)oxolane and 2-(phenylselanylmethyl)oxane as ligands. J. Inorg. Biochem. 2015, 143, 9-19. [CrossRef] [PubMed]

148. Choo, K.B.; Mah, W.L.; Lee, S.M.; Lee, W.L.; Cheow, Y.L. Palladium complexes of bidentate pyridine $N$-heterocyclic carbenes: Optical resolution, antimicrobial and cytotoxicity studies. Appl. Organomet. Chem. 2018, 32, e4377. [CrossRef]

149. Farkasová, V.; Drweesh, S.A.; Lüköová, A.; Sabolová, D.; Radojević, I.D.; Čomić, L.R.; Vasić, S.M.; Paulíková, H.; Fečko, S.; Balašková, T.; et al. Low-dimensional compounds containing bioactive ligands. Part VIII: DNA interaction, antimicrobial and antitumor activities of ionic 5,7-dihalo-8-quinolinolato palladium(II) complexes with $\mathrm{K}^{+}$and $\mathrm{Cs}^{+}$cations. J. Inorg. Biochem. 2017, 167, 80-88. [CrossRef]

150. Gorle, A.K.; Li, X.; Primrose, S.; Li, F.; Feterl, M.; Kinobe, R.T.; Heimann, K.; Warner, J.M.; Keene, F.R.; Collins, J.G. Oligonuclear polypyridylruthenium(II) complexes: Selectivity between bacteria and eukaryotic cells. J. Antimicrob. Chemother. 2016, 71, 1547-1555. [CrossRef]

151. Laurent, Q.; Batchelor, L.K.; Dyson, P.J. Applying a Trojan Horse Strategy to Ruthenium Complexes in the Pursuit of Novel Antibacterial Agents. Organometallics 2018, 37, 915-923. [CrossRef]

152. Li, F.; Feterl, M.; Mulyana, Y.; Warner, J.M.; Collins, J.G.; Keene, F.R. In vitro susceptibility and cellular uptake for a new class of antimicrobial agents: Dinuclear ruthenium(II) complexes. J. Antimicrob. Chemother. 2012, 67, 2686-2695. [CrossRef] [PubMed]

153. Liu, X.; Sun, B.; Kell, R.E.M.; Southam, H.M.; Butler, J.A.; Li, X.; Poole, R.K.; Keene, F.R.; Collins, J.G. The Antimicrobial Activity of Mononuclear Ruthenium(II) Complexes Containing the dppz Ligand. ChemPlusChem 2018, 83, 643-650. [CrossRef]

154. Onar, G.; Gürses, C.; Karataş, M.O.; Balcıoğlu, S.; Akbay, N.; Özdemir, N.; Ateş, B.; Alıc1, B. Palladium(II) and ruthenium(II) complexes of benzotriazole functionalized $N$-heterocyclic carbenes: Cytotoxicity, antimicrobial, and DNA interaction studies. J. Organomet. Chem. 2019, 886, 48-56. [CrossRef]

155. Pahontu, E.; Paraschivescu, C.; Ilies, D.C.; Poirier, D.; Oprean, C.; Paunescu, V.; Gulea, A.; Rosu, T.; Bratu, O. Synthesis and Characterization of Novel Cu(II), Pd(II) and Pt(II) Complexes with 8-Ethyl-2hydroxytricyclo(7.3.1.0(2,7))tridecan-13-one-thiosemicarbazone: Antimicrobial and in Vitro Antiproliferative Activity. Molecules 2016, 21, 674. [CrossRef] [PubMed]

156. Patra, S.C.; Saha Roy, A.; Banerjee, S.; Banerjee, A.; Das Saha, K.; Bhadra, R.; Pramanik, K.; Ghosh, P. Palladium(II) and platinum(II) complexes of glyoxalbis( $N$-aryl)osazone: Molecular and electronic structures, anti-microbial activities and DNA-binding study. New J. Chem. 2019, 43, 9891-9901. [CrossRef]

157. Satheesh, C.E.; Raghavendra Kumar, P.; Sharma, P.; Lingaraju, K.; Palakshamurthy, B.S.; Raja Naika, H. Synthesis, characterisation and antimicrobial activity of new palladium and nickel complexes containing Schiff bases. Inorg. Chim. Acta 2016, 442, 1-9. [CrossRef]

158. Southam, H.M.; Butler, J.A.; Chapman, J.A.; Poole, R.K. Chapter One-The Microbiology of Ruthenium Complexes. Adv. Microb. Physiol. 2017, 71, 1-96.

159. Turel, I.; Kljun, J.; Perdih, F.; Morozova, E.; Bakulev, V.; Kasyanenko, N.; Byl, J.A.; Osheroff, N. First ruthenium organometallic complex of antibacterial agent ofloxacin. Crystal structure and interactions with DNA. Inorg. Chem. 2010, 49, 10750-10752. [CrossRef] 
160. Yang, Y.; Liao, G.; Fu, C. Recent Advances on Octahedral Polypyridyl Ruthenium(II) Complexes as Antimicrobial Agents. Polymers 2018, 10, 650. [CrossRef]

161. Jević, V.V.; Radić, G.P.; Stefanović, O.D.; Radojević, I.D.; Vasić, S.; Čomić, L.R.; Đinović, V.M.; Trifunović, S.R. Part XXIII. Synthesis and characterization of platinum(IV) complexes with $O, O^{\prime}$-dialkyl esters of $(S, S)$-ethylenediamine- $N, N^{\prime}$-di-2-(3-methyl)butanoic acid and bromido ligands. Antimicrobial, antibiofilm and antioxidant screening. Inorg. Chim. Acta 2016, 442, 105-110. [CrossRef]

162. Dkhar, L.; Banothu, V.; Kaminsky, W.; Kollipara, M.R. Synthesis of half sandwich platinum group metal complexes containing pyridyl benzothiazole hydrazones: Study of bonding modes and antimicrobial activity. J. Organomet. Chem. 2020, 914, 121225. [CrossRef]

163. Sankarganesh, M.; Vijay Solomon, R.; Dhaveethu Raja, J. Platinum complex with pyrimidine- and morpholine-based ligand: Synthesis, spectroscopic, DFT, TDDFT, catalytic reduction, in vitro anticancer, antioxidant, antimicrobial, DNA binding and molecular modeling studies. J. Biomol. Struct. Dyn. 2020, 1-13. [CrossRef] [PubMed]

164. Choo, K.B.; Lee, S.M.; Lee, W.L.; Cheow, Y.L. Synthesis, characterization, in vitro antimicrobial and anticancer studies of new platinum $\mathrm{N}$-heterocyclic carbene (NHC) complexes and unexpected nickel complexes. J. Organomet. Chem. 2019, 898, 120868. [CrossRef]

165. Musa, T.M.; Al-jibouri, M.N.; Al-bayati, R.I.H. Synthesis, Characterization and Antimicrobial Study of nickel(II), palladium(II), platinum(II), rhodium(III), cadmium(II) and zirconium(IV) complexes with (E)-1-(benzo[d]thiazol-2-yl)-4-(hydroxy(2-hydroxyphenyl)methylene)-3-methyl-1H-pyrazol-5(4H)-one. J. Phys. Conf. Ser. 2018, 1032, 012057. [CrossRef]

166. Bobinihi, F.F.; Onwudiwe, D.C.; Ekennia, A.C.; Okpareke, O.C.; Arderne, C.; Lane, J.R. Group 10 metal complexes of dithiocarbamates derived from primary anilines: Synthesis, characterization, computational and antimicrobial studies. Polyhedron 2019, 158, 296-310. [CrossRef]

167. Stojković, D.L.; Jevtić, V.V.; Radić, G.P.; Đukić, M.B.; Jelić, R.M.; Zarić, M.M.; Anđelković, M.V.; Mišić, M.S.; Baskić, D.D.; Trifunović, S.R. Stereospecific ligands and their complexes. XXIV. Synthesis, characterization and some biological properties of $\mathrm{Pd}(\mathrm{II})$ and $\mathrm{Pt}(\mathrm{II})$ complexes with $\mathrm{R}_{2}$-S,S-eddtyr. New J. Chem. 2018, 42, 3924-3935. [CrossRef]

168. Ahmad, S.; Seerat ur, R.; Rüffer, T.; Khalid, T.; Isab, A.A.; Al-Arfaj, A.R.; Saleem, M.; Khan, I.U.; Choudhary, M.A. Crystal structure and antimicrobial activity of a transplatin adduct of $N, N^{\prime}$-dimethylthiourea, trans-[Pt( $\left.\left(\mathrm{NH}_{3}\right)_{2}(\mathrm{dmtu})_{2}\right] \mathrm{Cl}_{2}$. Monatsh. Chem. 2017, 148, 669-674. [CrossRef]

169. Onwudiwe, D.C.; Ekennia, A.C.; Mogwase, B.M.S.; Olubiyi, O.O.; Hosten, E. Palladium(II) and platinum(II) complexes of $N$-butyl- $N$-phenyldithiocarbamate: Synthesis, characterization, biological activities and molecular docking studies. Inorg. Chim. Acta 2016, 450, 69-80. [CrossRef]

170. Kaushal, M.; Lobana, T.S.; Nim, L.; Bala, R.; Arora, D.S.; Garcia-Santos, I.; Duff, C.E.; Jasinski, J.P. Synthesis of 2-acetylpyridine- $N$-substituted thiosemicarbazonates of copper(II) with high antimicrobial activity against methicillin resistant S. aureus, K. pneumoniae 1 and C. albicans. New J. Chem. 2019, 43, 11727-11742. [CrossRef]

171. Oladipo, S.D.; Omondi, B.; Mocktar, C. Synthesis and structural studies of nickel(II)- and copper(II)$N, N^{\prime}$-diarylformamidine dithiocarbamate complexes as antimicrobial and antioxidant agents. Polyhedron 2019, 170, 712-722. [CrossRef]

172. Krishnegowda, H.M.; Karthik, C.S.; Marichannegowda, M.H.; Kumara, K.; Kudigana, P.J.; Lingappa, M.; Mallu, P.; Neratur, L.K. Synthesis and structural studies of 1-phenyl-1,3-butanedione copper(II) complexes as an excellent antimicrobial agent against methicillin-resistant Staphylococcus aureus. Inorg. Chim. Acta 2019, 484, 227-236. [CrossRef]

173. Tiekink, E.R.T. Gold compounds in medicine: Potential anti-tumour agents. Gold Bull. 2003, 36, 117-124. [CrossRef]

174. Glišić, B.Đ.; Djuran, M.I. Gold complexes as antimicrobial agents: An overview of different biological activities in relation to the oxidation state of the gold ion and the ligand structure. Dalton Trans. 2014, 43, 5950-5969. [CrossRef] [PubMed]

175. Savić, N.D.; Milivojevic, D.R.; Glišić, B.Đ.; Ilic-Tomic, T.; Veselinovic, J.; Pavic, A.; Vasiljevic, B.; Nikodinovic-Runic, J.; Djuran, M.I. A comparative antimicrobial and toxicological study of gold(III) and silver(I) complexes with aromatic nitrogen-containing heterocycles: Synergistic activity and improved selectivity index of $\mathrm{Au}(\mathrm{III}) / \mathrm{Ag}(\mathrm{I})$ complexes mixture. RSC Adv. 2016, 6, 13193-13206. [CrossRef] 
176. Hikisz, P.; Szczupak, L.; Koceva-Chyla, A.; Gu Spiel, A.; Oehninger, L.; Ott, I.; Therrien, B.; Solecka, J.; Kowalski, K. Anticancer and Antibacterial Activity Studies of Gold(I)-Alkynyl Chromones. Molecules 2015, 20, 19699-19718. [CrossRef]

177. Schmidt, C.; Karge, B.; Misgeld, R.; Prokop, A.; Brönstrup, M.; Ott, I. Biscarbene gold(I) complexes: Structure-activity-relationships regarding antibacterial effects, cytotoxicity, TrxR inhibition and cellular bioavailability. Med. Chem. Commun. 2017, 8, 1681-1689. [CrossRef]

178. Pöthig, A.; Ahmed, S.; Winther-Larsen, H.C.; Guan, S.; Altmann, P.J.; Kudermann, J.; Santos Andresen, A.M.; Gjøen, T.; Høgmoen Åstrand, O.A. Antimicrobial Activity and Cytotoxicity of Ag(I) and Au(I) Pillarplexes. Front. Chem. 2018, 6, 584. [CrossRef]

179. Crichton, R. Biological Inorganic Chemistry, 3rd ed.; Elsevier: London, UK, 2019; pp. $339-362$. ISBN 978-0-12-811741-5.

180. Cuevas, L.; Koyanagi, A. Zinc and infection: A review. Ann. Trop. Paediatr. 2005, 25, 149-160. [CrossRef]

181. Harrison, P.M.; Hoare, R.J. Metals in Biochemistry; Chapman and Hall: London, UK; New York, NY, USA, 1980.

182. Osredkar, J. Copper and Zinc, Biological Role and Significance of Copper/Zinc Imbalance. J. Clin. Toxicol. 2011, 3, 495. [CrossRef]

183. Zelenak, V.; Gyoryova, K.; Mlynarcik, D. Antibacterial and Antifungal Activity of Zinc(II) Carboxylates with/without N-Donor Organic Lligands. Met. Based Drugs 2002, 8, 269-274. [CrossRef]

184. Zaltariov, M.-F.; Cazacu, M.; Avadanei, M.; Shova, S.; Balan, M.; Vornicu, N.; Vlad, A.; Dobrov, A.; Varganici, C.-D. Synthesis, characterization and antimicrobial activity of new $\mathrm{Cu}(\mathrm{II})$ and $\mathrm{Zn}(\mathrm{II})$ complexes with Schiff bases derived from trimethylsilyl-propyl-p-aminobenzoate. Polyhedron 2015, 100, 121-131. [CrossRef]

185. Abu Ali, H.; Omar, S.N.; Darawsheh, M.D.; Fares, H. Synthesis, characterization and antimicrobial activity of zinc(II) ibuprofen complexes with nitrogen-based ligands. J. Coord. Chem. 2016, 69, 1110-1122. [CrossRef]

186. Boughougal, A.; Cherchali, F.Z.; Messai, A.; Attik, N.; Decoret, D.; Hologne, M.; Sanglar, C.; Pilet, G.; Tommasino, J.B.; Luneau, D. New model of metalloantibiotic: Synthesis, structure and biological activity of a zinc(II) mononuclear complex carrying two enrofloxacin and sulfadiazine antibiotics. N. J. Chem. 2018, 42, 15346-15352. [CrossRef]

187. Basu Baul, T.; Nongsiej, K.; Ka-Ot, A.; Joshi, S.R.; León, I.; Höpfl, H. Tweaking the affinity of aryl-substituted diazosalicylato- and pyridine ligands towards $\mathrm{Zn}(\mathrm{II})$ and its neighbors in the periodic system of the elements, $\mathrm{Cu}(\mathrm{II})$ and $\mathrm{Cd}(\mathrm{II})$, and their antimicrobial activity. Appl. Organomet. Chem. 2019, 33, e4905. [CrossRef]

188. Staneva, D.; Vasileva-Tonkova, E.; Grabchev, I. A New Bioactive Complex between Zn(II) and a Fluorescent Symmetrical Benzanthrone Tripod for an Antibacterial Textile. Materials 2019, 12, 3473. [CrossRef]

189. Bahojb Noruzi, E.; Shaabani, B.; Geremia, S.; Hickey, N.; Nitti, P.; Kafil, H.S. Synthesis, Crystal Structure, and Biological Activity of a Multidentate Calix[4]arene Ligand Doubly Functionalized by 2-Hydroxybenzeledene-Thiosemicarbazone. Molecules 2020, 25, 370. [CrossRef]

190. Montazerozohori, M.; Nasr-Esfahani, M.; Hoseinpour, M.; Naghiha, A.; Zahedi, S. Synthesis of some new antibacterial active cadmium and mercury complexes of 4-(3-(2-(4-(dimethyl aminophenyl allylidene aminopropyl-imino)prop-1-ethyl)-N,N-dimethyl benzene amine. Chem. Spec. Bioavailab. 2014, 26, 240-248. [CrossRef]

191. Agertt, V.A.; Bonez, P.C.; Rossi, G.G.; Flores, V.d.C.; Siqueira, F.d.S.; Mizdal, C.R.; Marques, L.L.; de Oliveira, G.N.M.; de Campos, M.M.A. Identification of antimicrobial activity among new sulfonamide metal complexes for combating rapidly growing mycobacteria. BioMetals 2016, 29, 807-816. [CrossRef]

192. Matiadis, D.; Tsironis, D.; Stefanou, V.; Elliott, A.G.; Kordatos, K.; Zahariou, G.; Ioannidis, N.; McKee, V.; Panagiotopoulou, A.; Igglessi-Markopoulou, O.; et al. Synthesis, characterization and antimicrobial activity of $\mathrm{N}$-acetyl-3-acetyl-5-benzylidene tetramic acid-metal complexes. X-ray analysis and identification of the Cd(II) complex as a potent antifungal agent. J. Inorg. Biochem. 2019, 194, 65-73. [CrossRef]

193. Mandal, S.; Mondal, M.; Biswas, J.K.; Cordes, D.B.; Slawin, A.M.Z.; Butcher, R.J.; Saha, M.; Chandra Saha, N. Synthesis, characterization and antimicrobial activity of some nickel, cadmium and mercury complexes of 5-methyl pyrazole-3yl-N-(2'-methylthiophenyl) methyleneimine, (MPzOATA) ligand. J. Mol. Struct. 2018, 1152, 189-198. [CrossRef] 
194. Mandal, S.; Das, M.; Das, P.; Samanta, A.; Butcher, R.J.; Saha, M.; Alswaidan, I.A.; Rhyman, L.; Ramasami, P.; Saha, N.C. Synthesis, characterization, DFT and antimicrobial studies of transition metal ion complexes of a new schiff base ligand, 5-methylpyrazole-3yl- $N$-(2'-hydroxyphenylamine)methyleneimine, (MPzOAP). J. Mol. Struct. 2019, 1178, 100-111. [CrossRef]

195. Lam, P.L.; Lu, G.L.; Choi, K.H.; Lin, Z.; Kok, S.H.L.; Lee, K.K.H.; Lam, K.H.; Li, H.; Gambari, R.; Bian, Z.X.; et al. Antimicrobial and toxicological evaluations of binuclear mercury(II) bis(alkynyl) complexes containing oligothiophenes and bithiazoles. RSC Adv. 2016, 6, 16736-16744. [CrossRef]

196. Wang, H.; Qian, X.; Wang, K.; Su, M.; Haoyang, W.-W.; Jiang, X.; Brzozowski, R.; Wang, M.; Gao, X.; Li, Y.; et al. Supramolecular Kandinsky circles with high antibacterial activity. Nat. Commun. 2018, 9, 1815. [CrossRef] [PubMed]

(C) 2020 by the authors. Licensee MDPI, Basel, Switzerland. This article is an open access article distributed under the terms and conditions of the Creative Commons Attribution (CC BY) license (http://creativecommons.org/licenses/by/4.0/). 